\title{
HAKİKAT VE MECAZ BAĞLAMINDA KUR'AN'DA MESH (MAYMUNLAŞMA) HADİSESİ
}

\author{
Mustafa TUNÇER ${ }^{\mathrm{a}}$
}

$\ddot{0} \mathbf{z}$

Kur'ân'ın inceliklerini araștıran ilimlerden biri olan hakikat ve mecaz ilmi, Kur'ân ilimleri arasında en fazla üzerinde tartışılan konular arasında yer alır. İslâm âlimlerinin bir kısmı Kur'ân'da mecazın olmadığını iddia ederken, çoğunluğu da mecazın varlığını kabul etmektedir. Kur'ân-ı Kerim'in tefsiri sırasında âyetlerde geçen bazı ifadelere hakikat veya mecaz anlamının verilip verilmemesi konusunda müfessirler arasında tartışmalar yaşanmaktadır. Başta Allah'ın sıfatları olmak üzere pek çok alanda bu ihtilaflara rastlamak mümkündür. Hatta bu durum bazı kıssalarda da kendini gösterir. Örneğin Allah'ın Yahudilere yönelik Cumartesi günü için koyduğu avlanma yasağına aldırış etmeyen bir topluluğun maymuna dönüștürülmesi hadisesinin anlatıldığı kıssada da yer alır. Söz konusu bu kıssada dile getirilen "aşağıllk maymunlar olun" ifadesinin gerçek anlamında hem suret (görüntü) hem de karakter açısından maymuna çevrilmesi mi, yoksa bu dönüşümün yasağı çiğneyen kişilere yönelik bir aşağılama anlamı mı taşıdığı noktasında hakikat-mecaz kavramları açısından farklı yorumlar yapılmaktadır.

Kur'ân'da birkaç farklı surede gündeme gelen bu hadisenin Kur'ân ilimleri arasında yer alan hakikat-mecaz ilmi açısından hangi usulde gerçekleştiği ve bunun bir çeşit reenkarnasyon olup olamayacağı konusu tartışmaya açılmaktadır. Bu kapsamda ilgili tüm âyetlerin birbiriyle olan bağlantısı, âyetlerdeki kesinlik bildiren ifadeler ve ibretlik bir vaka oluşuna yapılan vurgular birlikte düşünüldüğünde mesh hadisesinin suret ve karakter değişiminin hakikat anlamında alınması gerektiği kanaati oluşmakta ve bu olayın reenkarnasyonla bir bağının bulunmadığı değerlendirilmektedir.

Anahtar kelimeler: Tefsir, Kur'ân, Hakikat ve Mecaz, Mesh, Reenkarnasyon.

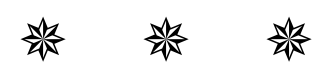

\footnotetext{
a Dr. Öğr. Üyesi, Giresun Üniversitesi, mustafatuncer061@hotmail.com
} 


\section{THE EVENT OF SIMIANIZATION IN THE CONTEXT OF TRUTH AND METAPHOR IN THE QUR'AN}

The science of truth and metaphor, which is one of the sciences that investigate the subtleties of the Qur'an, is among the most discussed topics among the sciences of the Qur'an. While some of the Islamic scholars claim that there is no metaphor in the Qur'an, most of them accept the existence of metaphors and state that the metaphors enrich the literary style of the Qur'an, being a more eloquent way of expression than the truth itself.

Although it is essential to use the literal meaning in the language, sometimes the figurative meaning can be used due to falling short of words or the inability to use words effectively. For example, if a person dies after saying that "I allocate my property to my children", all of his sons and daughters are understood as the literal meaning. As an example of figurative expression, if someone says that "I ate from that tree", he means eating fruits from that tree. According to those who do not agree on the usage of metaphors, someone only uses metaphors when he could not make himself understood. So, since it is unthinkable for Allah, there cannot be any metaphor in the Qur'an. According to the scholars who accept the existence of metaphors in the Qur'an, metaphor, as used in the Qur'an is not a metaphor in this sense. While Allah never had any difficulties in using metaphors, Allah used metaphors to increase the effectiveness of the meanings contained in the divine word and to add beauty and richness to the word.

[The Extended Abstract is at the end of the article.]

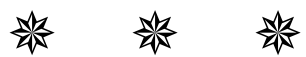

\section{Giriş}

İnsanoğlu, dünyada fitrî niteliklerini geliştirip hayatını şekillendirme sürecinde Allah'ın gönderdiği elçi ve kitapların rehberliğinde istikametini çizmeye çalışmaktadır. Bu süreçte kendisine uyması için bir takım kurallar sunulmakta ve aksine hareket edildiğinde karşılaşabileceği sonuçlara da katlanmak zorunda olduğu bildirilmektedir. İnsanlık tarihi, inançsızlıkları veya bu doğrultudaki yanlış hareketleri nedeniyle pek çok ibretlik vaka ile doludur. Kur'ân'da kötü sonla neticelenen vakalara bakıldığında bunların arka planındaki olaylar ve cezanın verilme gerekçeleri muhataplara sunulmaktadır. Bu bağlamda insanların başıboş yaratılmadığı ${ }^{1}$ karşılaştığı bu türden ceza-i müeyyidelerin müsebbibinin de yine kendisi olduğu belirtilmektedir. $^{2} \mathrm{Bu}$ kıssalarda Yüce Allah'ın güç ve kudretine vurgu

${ }^{1}$ Kur'ân-ı Kerim ve Yüce Meali, çev. Süleyman Ateş (İstanbul: Yeni Ufuklar Neşriyat, ts.), Yûnus 10/13.

2 el-Enbiyâ 21/11. 
yapılarak dilediği her şeyi yaptığı, tüm varlıkların kendi iradesine bağlı olduğu, yaptıklarından da kimseye karşı sorumlu olmadığı açıcça dile

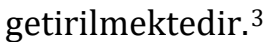

Tarihte kurallara uymayan pek çok topluluğun karşılaştığı kötü sona benzer şekilde bir grup Yahudi'nin de uyarıları dikkate almadıkları için maymuna çevrildiği Kur'ân'da bazı âyetlerde anlatılmaktadır. Söz konusu bu hadise müfessirler arasında sonuçları açısından değerlendirilmekte ve âyetlerde geçen kavramların hakikat mi yoksa mecaz anlamında mı alınması hususunda iki ayrı görüş etrafında yorumlar yapılmaktadır. Bu iki yorumdan ilki, âyetin hadisenin âleme ibret olduğu vurgusu da dikkate alınarak hakiki anlamının tercih edilmesi gerektiğine odaklanmaktadır. Az sayıda müfessirin benimsediği ikinci görüşe göre ise, bu âyetlerin hakiki anlamlarının yerine mecaz anlamının kullanılması gerektiğine temas edilmektedir. Bu konuya dair günümüze ulaşan müstakil kitaplar (tespit edebildiğimiz kadarı ile) bulunmamakla birlikte tefsir literatürü içerisinde ilgili âyetler bağlamında konu ele alınıp değerlendirilmiştir. Makale türünde hazırlanan çalışmalarda da konu daha çok kavramsal çerçeve içerisinde işlenmiştir. Bu makalede klasik dönem tefsirleri başta olmak üzere çağdaş tefsir kaynakları da taranarak mesh hadisesinin hakikat ya da mecaz olarak algilanmasina dair görüşler değerlendirmeye tabi tutulmakta ve bir kanaate ulaşılmaya çalışılmaktadır.

$\mathrm{Bu}$ çalışmada Yüce Allah'ın koyduğu kurallara uymayan İsrailoğullarından bir grubun maymuna çevrilmesi konusu hakikat ve mecaz kavramları bağlamında ele alınmaktadır. Konunun çerçevesi sadece cezaya çarptırılan grupla sınırlı kalmakla birlikte benzeri uyarıları dikkate almayan topluluklara da uygulanan cezalara örnek kabilinden değinilmektedir.

\section{A. Hakikat ve Mecaz}

İnsanın düşüncelerini ifade etmede kullandığı üsluplardan birisi hakikat ve mecaz olgusudur. Ancak bu iki kavram sahibinin maksadını okuyabilme ve anlamlandırmada zorluk çlkarabilmektedir. Mecaz, hakiki mananın dışındaki bir manada kullanılan lafız anlamına gelirken, ilk akla gelen veya karinesiz anlaşılan anlamı da hakikat olarak tanımlanmaktadır. ${ }^{4}$ İfade sahibinin sözlerinden hakikat manasını mı yoksa mecaz anlamını mı kastettiği bazen anlaşılamamakta ve ifadenin anlaşılmasında karışılklığa sebep olabilmektedir. Hakikat, ifade edildiği manada kullanılan sözü ifade

3 el-Enbiyâ 21/23.

4 Mecduddin Muhammed b. Yakub el-Fîrûzâbâdî, Besâîru zevi't-temyîz fî letâifi'l-Kitâbi'l- 
ederken; mecaz ise bir ilgi, karine veya bağlantı sebebiyle asıl mananın dışında başka bir anlam kazanması ${ }^{5}$ şeklinde tarif edilmektedir. Mecaz, kelimenin asli anlamın ötesinde kullanım sıklığına bağlı olarak geçici olarak kazandığı anlamdır. Bu durum aslında dildeki zenginliğin veya çeşitliliğ̈in ifadesidir. Bu yüzden çoğu dilde mecazî kullanım vazgeçilmez bir unsurdur. Örneğin sevgimizi ifade etmek için bir öğrencimize "Kuzum ne haber?" diye seslendiğimizde kastımız koyunun yavrusu olan kuzu olmadığı gibi "Aslan yine sahne aldı" sözünde de maksat ormanların kralı diye tarif edilen aslan da değildir.

Dilde hakiki manayı kullanmak esas olmakla birlikte bazen kelimelerin yetersizliği veya etkili kullanılamaması yüzünden mecazî anlam kullanılabilmektedir. Bu husus Ahmet Cevdet Paşa'nın (ö. 1895) hazırladığı Mecelle'de de kaide hüviyetiyle iki ayrı madde halinde şu şekilde yer almaktadır: "Kelâmda asıl olan manây-ı hakîkidir". "Manây-i hakîki müteazzir (yetersiz) oldukta mecaza gidilir". ${ }^{6}$ Örneğin bir kişinin "Mallarımı çocuklarıma pay ettim" sözünden sonra vefatı halinde kullandığı bu ifadeden kız-erkek tüm evladının anlaşılması hakiki anlamıdır. Mecazî kullanım için de "Şu ağaçtan yedim" diyen birinin ağacın meyvesini yemeyi kastetmiş olması mecaza örnek verilebilir.

Mecaz kavramının kullanımı kültürler arasında farklılık arz eder. Örneğin "eli uzun" ifadesi Türk kültüründe "hırsızlı" anlamında kullanılırken Arap örfünde cömertlik anlamı taşır. Zira Hz. Peygamber'in eşlerinden birinin "Hangimiz sana daha önce kavuşacağız?" sorusuna kendisi, "eli uzun olan" şeklinde cevap vermiştir. ${ }^{7} \mathrm{~Hz}$. Peygamber'in yanında bulunan sahabe, onun bu ifadesinden cömertliği kastettiğini anlamışlardır. ${ }^{8}$

Kur'ân'ın ifadelerinde hakiki anlamların kullanılması konusunda âlimler arasında bir uzlaşı söz konusudur. Ancak âyetlerde mecazî anlamın kullanılıp kullanılmaması veya caiz olup olmamasına ilişkin alimler arasında bir fikir birliğinden söz edilemez. Müslüman âlimlerin çoğunluğu Kur'ân'da çeşitli konular bağlamında yer alan mecazın varlığını kabul ederken, bir kısmı ise Kur'ân'da mecazî kullanımın mümkün olmadığını iddia etmişlerdir. Zahirî mezhebinin kurucusu olarak kabul edilen Dâvûd ez-Zahirî (270/883),

\footnotetext{
${ }^{5}$ Seyyid Şerif Cürcânî, Kitâbu't-Tâ'rifât (Lübnan: Mektebetü Lübnan, 1985), "mecâz", 94.

${ }^{6}$ Mecelle 12. ve 61. mad. Bk. Ahmet Cevdet Paşa, Mecelle-i Ahkâm-ı Adliyye (Dersaadet: Matbaa-i Osmaniyye, 1308), 23, 30.

7 Ebû Abdullâh Muhammed b. İsmâîl b. İbrâhîm el-Buhârî, el-Câmi'u's-sahîh (İstanbul: Çağrı Yayınları, 1981), "Zekât" 11.

8 Abdülhamit Birışık, "Mecâzu'l-Kur'ân", Türkiye Diyanet Vakfi İslâm Ansiklopedisi (Ankara: TDV Yayınları, 2003), 28/323.
} 
oğlu Muhammed (297/910), Şafiî âlimlerinden İbnü'l-Kass diye tanınan Ahmed b. Ahmed et-Taberî (355/946), Malikîlerden Huveyz Mendâz (400/1009), Mutezilî âlim Ebû Müslim Muhammed b. Bahr el-İsfahânî (322/934) Muhyiddin İbnü'l-Arabî (638/1240), İbn Teymiyye (728/1328), İbn Kayyım el-Cevziyye (751/1350), Cemâleddin el-Kâsimî (1332/1914) gibi âlimler9 ${ }^{9}$ Kur'ân'da mecazın yer almadığını iddia etmişlerdir. ${ }^{10}$

Bu âlimlerin mecazı kabul etmemelerinin en temel sebebi, onu yalanın kardeşi olarak görmeleridir. Onlara göre bir kimse meramını istediği tarzda anlatamadığında mecaza başvurur. Oysa bu durum Allah için düşünülemeyeceğine göre Kur'ân'da mecaz olamaz. ${ }^{11}$ Mecazın varlığını kabul eden âlimlere göre ise Kur'ân'da kullanılan mecaz bu anlamda değildir. Allah mecazın kullanımında asla zorluk yaşamadığı gibi, ilahî kelâmın içerdiği manaların etkinliğini artırmak, kelama güzellik ve zenginlik kazandırmak, anlama genişlik ve derinlik katmak için mecaza yer vermiştir. Bu açıdan mecaz yalanın kardeşi değil, aksine anlatımı zenginleştiren edebi bir sanattır. ${ }^{12}$ Öyle ki, Celâleddin es-Suyûtî̀ye (ö. 911/1505) göre mecazların olmaması, Kur'ân'ın edebî güzelliklerinin bir kısmının kaybolacağı anlamına gelir. ${ }^{13} \mathrm{Bu}$ açıdan Kur'ân'ın, mesaj verirken dilini kullandığı muhatapların

9 Bedruddîn Muhammed b. Abdullah ez-Zerkeșî, el-Burhân fî 'ulûmi'l-Kur'ân, thk. Muhammed Ebü'l-Fazl İbrahim (Beyrut: Dârü'l-Ma'rife, ts.), 2/255; Subhi es-Sâlih, Mebâhis fì 'ulûmi'l-Kur'ân (İstanbul: Dersaadet, ts.), 329. Kur'ân'da mecazın bulunmadığını delillerle detaylı bir șekilde anlatan Cemâleddin el-Kâsımî, (öl. 1914) bașta mecazı kabul eden ilk dönem âlimleri olmak üzere günümüze kadar mecazı savunanların delillerini yine Kur'ân'dan verdiği örneklerle çürütmeye çalışır. Meselâ, "Kur'ân'da mecaz

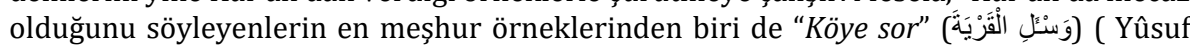
12/82.) âyetidir. Bu ifadeden kastedilen köy halkı olup "Köy halkına sor" demektir. İfadede 'tamlayan kaldırılmış, onun yerine tamlanan gelmiştir', derler. Onlara cevaben denir ki: Köy, şehir, nehir, miras vb. kelimelerden hem yer hem o yerde bulunan vardır, her ikisi de o isme dâhildir. Hüküm bazen o yerde bulunana, bazen de o yere döner." Bk. Cemâleddin Kasimî, Tefsir İlminin Temel Meseleleri, çev. Sezai Özel (İstanbul: İz Yayıncllık, 1990), 212.

10 Mustafa Öztürk, Kur'ân'da mecaz olmadığını savunan âlimler arasında Ebû Müslim elİsfahânî’nin zikredilmesinin yanlışlığını belirtmekte ve onun âyetlerde kullandığı mecaz örneklerini vererek bu konuya dair görüşünü teyit etmektedir. Bk. Mustafa Öztürk, Kur'ân'ın Mutezilî Yorumu Ebû Müslim el-İsfahânî Örneği (Ankara: Ankara Okulu Yayınları, 2008), 121-129.

11 Zerkeşî, el-Burhân, 2/255; Celâleddin Abdurrahman b. Ebî Bekr es-Suyûtî, el-Ittkân fî 'ulûmi'l-Kur'ân (Mısır: Mektebetü Dâri't-Türâs, ts.), 2/47.

12 Mesut Okumuş, "Ulûmü'l-Kur'ân”, Tefsir, ed. M. Akif Koç (Ankara: Grafiker Yayınları, 2015), 371.

13 Suyûtî, el-İtkân, 1/753. Edebi sanatlardan mecaza benzeyenlerden biri de kinayedir. Kinaye bir şeyi örtülü anlatmak demektir. Bazı âlimler kinayeyi mecazın bir çeşidi olarak kabul etmiştir. Örneğin; "Ne zaman ki o, eşini örtüp bürüdü; o da hafif bir yük yüklendi." (elA'râf 7/189.) âyetinde, insanın eşiyle birleşmesi ve onun da hamile kalması, kibar bir 
üslup biçimlerini de hesaba katmasında şaşılacak bir durum yoktur. Esasen olması gereken budur. Bu itibarla mecazı yalanla eșdeğerde görüp Kur'ân âyetlerinde mecazın bulunmadığını ifade etmek isabetli bir yaklaşım değildir. Şayet Kur'ân âyetlerinde mecaz bulunmuyorsa hazif, te'kid, kıssaların tekrar edilmesi gibi birtakım konuların da yer almaması gerekir. ${ }^{14}$ Kur'ân'ın belirli bir tarih diliminde vahyedildiği dolayısıyla, söz konusu tarih ve ilgili kültürel çevreyle sıkı bir ilişki içinde olduğu yadsınamaz bir durumdur.

Mecazın varlığını kabul etmeyenlerin ileri sürdükleri temel gerekçelerden birisi de "Bir mana, hakiki manalara delalet eden lafizlarla ifade edilemediğinde mecaza gidilir" şeklindeki görüşün çok isabetli olmadığı şu şekilde izah edilebilir: Çok üstün ifade ve söz söyleme sanatını ustalıkla kullanma becerisini gösteren şairlerin şiirlerinde mecazı ustalıkla kullanmış olmaları ifade güçlüğü çekildiğinde mecaza gidilir düşüncesinin yanlışlığını ortaya koyar. Mecazın, hakikatten daha üstün olduğunu vurgulayan belagat âlimleri de mecaza acizlikten değil üslubu güzelleştirdiği için müracaat ettiklerini belirtmektedirler. ${ }^{15}$

Bu konuda dil ve belagat yönünden farkındalık oluşturan bazı âyetler bağlamında konuyu değerlendirmek uygun olacaktır.

a. Enfâl sûresinin "Allah katında canlıların en kötüsü düşünmeyen sağırlar ve dilsizlerdir." (el-Enfâl 8/22) meâlindeki âyette; Allah'ın bildirdiklerine kulak asmayan, onları duymazlıktan gelen insanlar duyma özürlü kişilere benzetilerek bir mecaz yapılmıştır. ${ }^{16}$ Öte yandan buradaki kavramlar hakiki anlamında kullanılacak olsa bu ifadeden duyma ve konuşma özürlü olanların cezalı duruma düşeceği (kötü insanlar olduğu) anlamı ortaya çıkacaktır ki, bu durum Kur'ân'ın genel prensipleri ile zıtlık oluşturur.

b. “Onun yüzünden (zatından) başka her şey helak olacaktır." (el-Kasas 28/88) âyetinde geçen "vech" (yüz) kelimesinin hakîki anlamının yerine, "zatı" anlamının tercih edilmesi çok daha isabetli olacaktır. ${ }^{17}$

şekilde anlatılmıștır. Bk. Subhi es-Sâlih, Mebâhis fî 'ulûmi'l-Kur'ân, 329-330; Abdurrahman Çetin, Kur'ân İlimleri ve Kur'ân-ı Kerim Tarihi (İstanbul: Dergâh Yayınları, 2014), 275.

${ }_{14}$ Muhsin Demirci, Tefsirde Metodolojik Sorunlar (İstanbul: İFAV Yayınları, 2017), 197.

15 Ali b. Muhammed el-Âmîdî, el-İhkâm fî usûli'l-ahkâm (Beyrut: el-Mektebetü'l-İslâm, 1402), 1/46-48.

16 Ebû Abdullah Fahrüddîn Muhammed b. Ömer b. Hüseyin er-Râzî, et-Tefsîrü'l-kebîr (Beyrût: Dâru İhyâi't-Türâsi'l-Arabî, ts.), 15/149.

17 Mukâtil b. Süleyman, Tefsîru Mukâtil b. Süleyman (Beyrut: Müessesetü't-Târîhi'l-Arabî, 1423), 3/360; Ebû Ca'fer Muhammed b. Cerîr b. Yezîd et-Taberî, Câmi'u'l-beyân fî Tefsîri'l- 
c. "Rabbin gelip melekler de saf saf dizildiğinde," (el-Fecr 89/22) âyetinde Allah'ın gelmesi ifadesinin de hakikat anlamında anlaşılması yerine mecazî anlamda değerlendirilmesi gerekmektedir. Buna göre Rabbin gelmesi Allah'ın iktidar, saltanat ve üstünlük alametlerinin gözükeceğini anlatmaktadır. ${ }^{18}$

d. "Firavun dedi: Ey Hâmân, bana yüksek bir kule yap da o sebeplere (yollara) erişeyim.” (el-Mü'min 40/36) âyetinde de mecazî bir kullanım söz konusudur. Bu âyette aslında "kuleyi yapacak olan kimseye emret" şeklinde bir anlam olduğu çok açıktır. Zira devletin yöneticilerinden biri olan Hâmân'ın yüksek bir kuleyi kendi elleriyle yapması söz konusu olamaz. ${ }^{19}$

Kur'ân'da mecazî ifadelerin fazlaca yer almasının yanı sıra, kimi âlimler aklileştirme çabası içerisinde kantarın topuzunu fazla kaçırarak hakiki anlamların kullanımını engelleyen bir tavra sahip olmuşlardır. Mucizelerle ilgili yapılan bazı yorumlar bu yanlış yaklaşımın örneklerini oluşturmaktadır. Örneğin Hz. Îsâ'nın topraktan bir kuş sureti çıkarıp ona üflemesiyle kuş halini aldığından ${ }^{20}$ söz eden ifadeler bağlamında yapılan bazı açıklamalarda zahirî anlam dışında, Hz. Îsâ'ya inananların gelecek kaderlerinin şekillenmesi anlamına gelecek şekilde yorumlanmaktadır. ${ }^{21}$ Oysa konu Hz. Îsâ’nın diğer mucizelerinin anlatıldığı bir bağlamda geçmesinin yanı sıra mecaza gidilmesini gerektirecek bir amil de söz konusu değildir. Bu tür bir anlayış her ne kadar modern akılcı bir yaklaşımla konuyu yorumlama amacı taşıyorsa da bu derecede mecaza gitmek için burada yeterli bir neden yoktur. Olsa olsa bahsedilen yoruma, tefsir mahiyetindeki açıklamalarda yer verilebilir. ${ }^{22}$

Kur'ân'da yer alan bazı ifadelerin hakiki veya mecaz anlamında kullanımı konusundaki tartışmaların benzerleri fikıh alanında da mevcuttur. Örneğin hangi hallerde abdest alınması gerektiğine dair âyette geçen

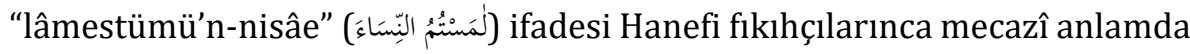

Kur'ân (Beyrût: Dârü'l-Ma'rife, 1407), 20/82; Suyûtî, el-İtkân, 2/38; Çetin, Kur'ân İlimleri ve Kur'ân-ı Kerim Tarihi, 275.

18 Ebû Mansûr Muhammed b. Muhammed el-Mâtürîdî, Te'vilâtü'l-Kur'ân (İstanbul: Dâru'lMîzân, 2005), 17/197-198; Zemahșerî, el-Keșşâf, 4/253; Ebü'l-A'lâ Mevdûdî, Tefhîmü'lKur'ân, çev. Muhammed Han Kayani - vd. (İstanbul: İnsan Yayınları, 1996), 7/120; Ali Karataş, "Müteşabih Ayetler ve Te'vili", Günümüz Tefsir Problemleri, ed. Ali Karataş Yunus Emre Gördük (Ankara: Bilay Yayınları, 2018), 153.

19 Suyûtî, el-İtkân, 2/97.

20 el-Mâide 5/110.

21 Muhammed Esed, Kur'ân Mesajı Meal ve Tefsîr, çev. Ahmet Ertürk, Cahit Koytak (İstanbul: İșaret Yayınları, 2002), 218.

${ }^{22}$ H. İbrahim Karslı, Kur'ân’ı Anlamaya Giriş (Ankara: DİB Yayınları, 2019), 128. 
algılanarak "cinsel ilişki"ye hamledilirken, diğer mezheplerce hakiki manasında "fizikî temas" olarak anlaşılmıştır. ${ }^{23}$ Bakara sûresinde beyaz ipliğin siyah iplikten ayırt edilinceye kadar yeme-içmeye müsaade edilmesinde de "beyaz ve siyah ip" ifadelerini hakiki anlamda alarak siyah ve beyaz renkli ipliklerle vaktin tespitini belirlemeye gayret eden Adi b. Hâtîm'e Resûlullah'ın bu tanımlamalardan amacın gecenin karanlığı ile gündüzün aydınlığı olduğunu ${ }^{24}$ ifade etmesi, söz konusu sözcüklerin mecaz anlamında kullanıldığının bir başka örneğini teșkil eder. ${ }^{25}$

Kısacası Kur'ân'ın edebî üslubuna üstün özellikler katan mecazın varlığı pek çok âyetle beraber ortaya konduktan sonra inkârı elbette güçleşmektedir. $\mathrm{Bu}$ itibarla âyetlerde mecazın olmadığını iddia etmek Kur'ân'ın bu yöndeki güzelliğini ortadan kaldırmak anlamı taşıyacağı için belagatçiler mecazın hakikaten daha beliğ bir anlatım şekli olduğu konusunda hemfikirdirler. ${ }^{26} \mathrm{Bu}$ itibarla bir grup İsrailoğlunun ceza olarak maymuna çevrilmesi konusu bağlamında işlenmesi önem arz etmektedir. Zira kimi müfessirlerin hakikat ilmi açısından bu meseleye yaklaşımı söz konusu iken, kimisi de mecaz ilmi kapsamında konuyu değerlendirdiği görülmektedir.

\section{B. Mesh Meselesiyle İlișkili Olarak Kur'ân'a Göre Bazı Toplulukların Cezalandırılması}

Cumartesi yasağını çiğneyenlerin maymuna çevrilme hadisesine geçmeden önce Allah'ın koyduğu kanunlara uymayanların tarihte ne şekilde cezalandırıldıklarını, bu olayların sonraki nesiller için nasıl ibretlik vaka teşkil ettiklerini öncelikle irdelemek konunun anlaşılmasına katkı sağlayacaktır.

İnsanın akıl ve irade gibi son derece klymetli meziyetlere sahip olması yönüyle bu dünyada eşref-i mahlûkât (varlıkların en değerlisi) olduğu şüphe götürmez bir gerçektir. Ne var ki insanın, bu denli öneme sahip potansiyel değerleri her zaman istenilen ölçülerde kullandığı söylenemez. İnsan kimi zaman söz konusu bu değerlere bağlı kalarak manevi değerini artırabilirken,

${ }^{23}$ Râzî, et-Tefsîrü'l-kebîr, 10/112-113; Ebû Abdullah Muhammed b. Ahmed el-Ensârî elKurtûbî, el-Câmi' li ahkâmi'l-Kur'ân (Beyrut: Dârü'l-Kâtibi'l-Arabî, 1387), 6/369-370.

${ }^{24}$ Ebü'l-Fidâ İmâdüddîn İsmâil İbn Kesir, Tefsîrü'l-Kur'âni'l-'Azîm (Beyrût: Dâru İhyâi'tTürâsi'l-Arabî, h. 1388), 1/220.

25 Demirci, Tefsirde Metodolojik Sorunlar, 196.

${ }^{26}$ Subhi es-Sâlih, Mebâhis fí 'ulûmi'l-Kur'ân, 329. Kur'ân'da mecaz konusuna dair geniș bilgi için bk. Hikmet Akdemir, "Kur'ân-ı Kerim'de Mecazın Varlığı Problemi”, Harran Üniversitesi İlahiyat Fakültesi Dergisi $4 / 4$ (1998), 59-90; Necdet Çăğl, "Hakikat-Mecaz Kutuplaşması Bağlamında Kur'an'da Temsilî (Simgesel) Anlatım”, İslâmî İlimler Dergisi 8/1 (2013), 95-114. 
ilahi emirlere uygun hareket etmediği takdirde değeri çok düşük konuma da inebilmektedir. ${ }^{27}$ Başka bir ifadeyle bunca nimetlere rağmen insan, kendisine tarif edilen kurallara uygun ${ }^{28}$ davranmayıp nankörlük ettiğinde, Kur'ân'ın tanımlamasına göre canlıların en şerlisi konumunda olmakta ${ }^{29}$ ya da hayvanlardan daha aşağı dereceye inmektedirler. ${ }^{30}$

Kur'ân'da, cezalandırılan toplulukların helâk edilme vakaları incelendiğinde bu toplulukların kendilerine azap tehdidi ile gelen peygamberlere karşı büyüklük taslamaları, ${ }^{31}$ başlarına gelen bela ve musibetlerden ders almamaları, ${ }^{32}$ Allah'ın âyetlerine, peygamberlerine inanmayıp inananlara zulmetmeleri nedeniyle ${ }^{33}$ cezaya çarptırıldıkları anlaşılmaktadır. Bu topluluklardan Nûh kavmi ile Firavun ve askerleri suda boğulmak suretiyle cezalandırılırken, ${ }^{34}$ Ad kavmi rüzgâr, ${ }^{35}$ Semûd ve Medyen kavmi sarsıntı, ${ }^{36}$ Lût kavmi taş yağmuru sonucu ${ }^{37}$ ve İsrailoğullarından bir grup da maymuna ve domuza çevrilmek ${ }^{38}$ suretiyle helâk edilmişlerdir. Bu son grubun cezalandırılma usulü aşağıda ayrıntılı olarak ele alınıp değerlendirilecektir.

Kur'ân'da bahsi geçen lanet okunup helak edilen topluluklara bakıldığında bunlar arasında İsrailoğullarının ayrı bir yeri olduğu açıkça görülecektir. Bu konuda Kur'ân, İsrailoğullarının, aymaz tavırları, kıskançlıkları, mala ve dünyaya aşırı düşkünlükleri ${ }^{39}$ yüzünden başlarından belaların eksik olmadığını; ilahî vahye karşı gelmeleri, indirilen vahiyleri değiştirmelerinden dolayı çeşitli azap ve musibetlere uğratıldıklarını, bunun yanı sıra belki uslanırlar diye affedildiklerini ${ }^{40}$ haber vermektedir. ${ }^{41}$

Buraya kadar Kur'an bütünlüğü içerisinde meshe benzer cezalandırmaların nasıl gerçekleștiği konusu kısaca değerlendirmeye alınmıştır. Şimdi ise meshin benzeri olan bu cezaların gaye ve

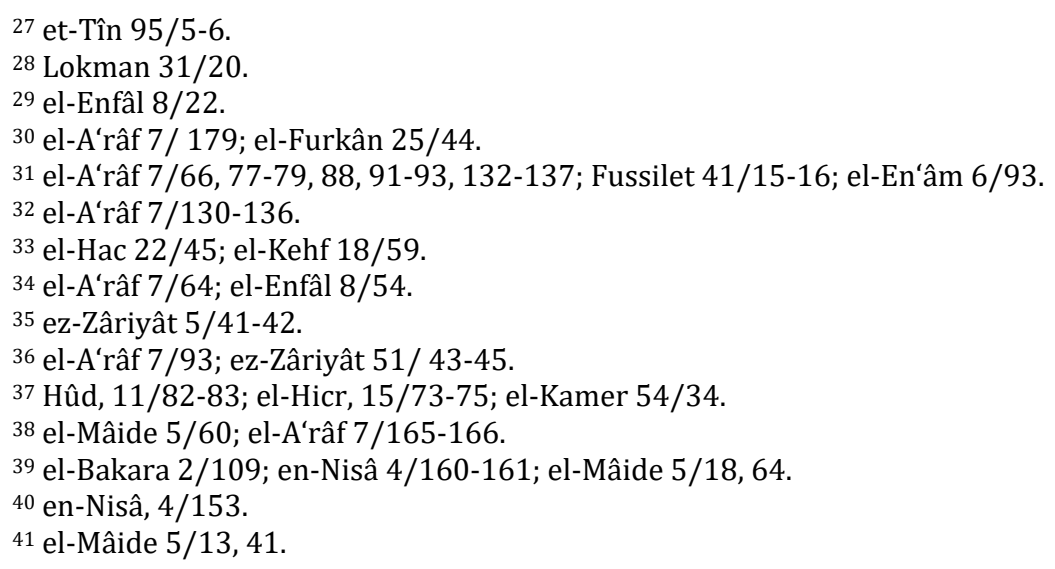


hikmetlerinden hareketle, meshin mahiyetine ışık tutacak ipuçları elde edilmeye çalışılacaktır.

\section{Kur'ân'da Mesh Hadisesi}

"Mesh" kelimesi sözlükte bir maddenin șeklini daha kötü bir șekle çevirmek, bir yiyeceğin tadını bozmak gibi anlamlara ${ }^{42}$ gelmektedir. Rağıb el-İsfahânî̀ye göre mesh iki türlü olabilir. Ya özel olan ve arada bir meydana gelen fizikî yaratılışın değişmesi ya da her zaman meydana gelebilen ahlakî

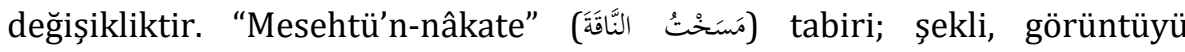
değişecek derecede deveyi yordum ve zayıflattım demektir. ${ }^{43}$

İnsanın çeşitli varlıklara dönüşümü için kaynaklarda dört farklı kavram kullanılmaktadır. Bu kavramlardan insanın başka bir insana dönüşümüne "nesh", insanın gerek fiziksel gerekse ahlakî açıdan daha kötü bir duruma dönüşümüne "mesh", insan bedeninin bitkilere intikaline "resh", maden ve cisimler gibi cansız varlıklara nakline de "fesh" adı verilmektedir. ${ }^{44}$ Şu halde meshin iki şekilde gerçekleştiğinden söz edilebilir. Mesh ya manevî yani ahlak ve karakterlerdeki gerileme ile sonuçlanan psikolojik değişim ya da ahlakî çöküntünün yanı sıra hayatî ve şekil/fizikî değişikliğini de içeren tümden bir dönüşümdür.

"Mesh" kelimesi Kur'ân'da sadece Yâsîn suresinin "Dilesek kılıklarını değiştirip onları oldukları yerde dondururduk, ne ileri gidebilir, ne geri dönebilirlerdi." (Yâsîn 36/67) âyetinde geçmektedir. Bu âyetten başka diğer âyetlerde kelime olarak "mesh" sözcügü kullanılmamasına rağmen insanların çirkin şekle dönüştürülmesi hususu dört ayrı sûrede gündeme gelmektedir. Bu yüzden Kur'ân'da İsrailoğullarından Cumartesi gününe özgü avlanma yasağını ihlal eden bir grubun maymuna ve domuza dönüştürüldügünü ifade eden âyetleri de mesh kavramı kapsamında değerlendirmek gerekir. Bu âyetler A'râf, Bakara, Mâide ve Nisâ sûrelerinde geçmektedir. ${ }^{45}$

42 İsmail b. Hammâd el-Cevherî, es-Sıhâh: Tâcü'l-luğe ve sıhâhi'l-Arabiyye (Beyrut: Dârü'lİlm, 1407/1987), "msh", 2/169; Rağıb el-İsfahânî, Müfredâtu elfâzi'l-Kur'ân, thk. Safvân Adnan Dâvûdî (Dımeșk: Dârü'l-Kalem, 1423/2002), “msh”, 768; Ebü'l-Fazl Cemâlüddîn Muhammed b. Mukerrem b. Alî İbn Manzûr, Lisânü'l-Arab (Beyrût: Dâru Lisâni'l-Arab, ts.), "msh", 3/55; Cürcânî, "mecâz", 212.

43 İsfahânî, "msh", 768.

${ }^{44}$ Adudüddin Abdurrahman b. Ahmed el-Îcî, Kitâbü'l-mevâkıf (Beyrut: Dârü'l-Cîl, 1997), 3/480, 483; M. Şemseddin Günaltay, Felsefe-i Ûlâ İsbat-ı Vacib ve Ruh Nazariyeleri, haz. Nuri Çolak (İstanbul: İnsan Yayınları, 1994), 161.

45 İlgili âyetler için bk. el-A'râf 7/163-166; el-Bakara 2/65; el-Mâide 5/60; en-Nisâ 4/47. 
Yüce Allah, İsrailoğulları için Cumartesi (Sebt) ${ }^{46}$ gününü ibadete tahsis etmiş ve çalışmalarını yasaklamıştır. ${ }^{47}$ Onlardan bir grup mesh vakasından önce pek çok kere aymazlık yapıp daha sonra bağışlanmış olduklarından olacak ki, bu yasağı ciddiye almamış ve bir hileye başvurarak avlanma yasağını delmişlerdir. $\mathrm{Bu}$ konu A'râf suresinde şu şekilde dile getirilmektedir:

"Onlara, deniz klyısinda bulunan kent (halk) In durumunu sor. Hani onlar Cumartesine saygısızlık edip haddi așıyorlardı. Çünkü Cumartesi (tatil) yapmadıkları gün, balıkları gelmezdi. Biz onları yoldan çıkmalarından ötürü böyle siniyorduk. İçlerinden bir topluluk: "Allah'ın helak edeceği yahut şiddetli bir şekilde azap edeceği bir kavme ne diye öğüt veriyorsunuz?" dedi. Dediler ki: "Rabbinize mazeret (beyan edebilmek) için, bir de belki korunurlar diye (öğüt veriyoruz)." Ne zaman ki onlar, kendilerine hatırlatılanı unuttular, biz de kötülükten menedenleri kurtardık; zulmedenleri de yoldan çıkmaları yüzünden çetin bir azap ile yakaladık. Kibirlerinden dolayı kendilerine yasak kılınan şeylerden vazgeçmeyince onlara: "Aşağllı maymunlar olun!" dedik. Rabbin, "Elbette ta klyamet gününe kadar onlara azabın en kötüsünü yapacak kimseler gönderecektir!" diye ilan etmişti. Doğrusu, Rabbin çabuk ceza

46 Arapçada Cumartesi günü anlamına gelen "sebt" kelimesi Yahudilikte ibadet etme ve istirahat günü olarak kabul edilmiștir. Yahudilerin Kutsal kitabı Tevrat'ta ("şabat") Allah'ın yeri ve gökleri pazar ile cuma arasında yedi günde yarattığı, sonra ise dinlendiği (Kitabı Mukaddes (İstanbul: Yeni Yaşam Yayınları, 2016), Tekvin 2/1-2.), İsrailoğullarından da bu günde istirahat etmelerini istediği (Çıkış 20/8-11.) bilgisi yer almaktadır. ("Sebt" kavramı için bk. Salime Leyla Gürkan, "Sebt", Türkiye Diyanet Vakfi İslâm Ansiklopedisi (İstanbul: TDV Yayınları, 2009), 36/256, 258; Nurettin Turgay, “Kur'ân'da Sebt Kavramı", Yalova Sosyal Bilimler Dergisi 2/4 (2012), 153-166; Yusuf Ağkuş - Abdullah Altuncu, "Yahudi Kutsal Metinlerinde ve Kur'ân'da Şabat (Cumartesi) Yasakları ve Mesh Hadisesi”, Insan ve Toplum Bilimleri Araştırmaları Dergisi 6/5 (2017), 2775-2794.)

47 “Cumartesi (gününü ta'til ve ibadet günü yapmak), onda ayrıllğa düşen(Yahudi)lere (farz) kılındı. Rabbin, elbette ayrılığa düştükleri şey hakkında kıyamet günü aralarında hükmünü verecektir.” (en-Nahl 16/124.) Müfessirler, Hz. Mûsâ'nın, varlıkların yaratılışının bittiği gün olan Cuma gününün ibadet günü olmasını Yahudilere söylemesine rağmen onların çoğunun Allah'ın yaratma ișini Cuma günü bitirmesi nedeniyle Cumartesi gününün ibadet günü olmasını istediklerini ifade ederler. Bu yüzden Allah, Cumartesi günü çalıșmayı onlara yasaklamıștır. İște âyette belirtilen ihtilaf noktası, Cumartesinin ibadet günü olup olmadığı ve bu günde çalışmanın yasaklanıp yasaklanmayacağı konusudur. (Bk. Ebü'l-Kâsım Mahmûd b. Ömer b. Muhammed el-Hârizmî ez-Zemahşerî, el-Keșşâf'an hakâiki't-tenzîl ve 'uyûni'l-ekâvîl (Beyrût: Dârü'l-Fikr, ts.), 2/125; Sait Şimșek, Hayat Kaynă̆ı Kur'ân Tefsiri (İstanbul: Beyan Yayınları, 2016), 3/191. Süleyman Ateş ise, Yahudilerin ihtilafının, Cumartesinin tatil günü olmasından değil, o günde avlanma yasağının bulunup bulunmaması üzerinde olduğunu ifade etmektedir. (Bk. Süleyman Ateş, Yüce Kur'ân'ın Çağdaş Tefsiri (İstanbul: Yeni Ufuklar Neşriyat, 1989), 5/158. 
verendir ve 0 , çok bağışlayan, çok esirgeyendir." (el-A'râf 7/163167).

Klasik tefsir kaynakları yasağa uymayan bu grubun, kıyıda havuzlar hazırlayıp bu havuzları kanallarla denize bağladıklarını, bu kanallarda balıkların geri dönüşünü engelleyen barikatlar kurduklarını ve bu sayede Pazar günü balıkları avladıklarını bildirmektedir. Yine bu kaynaklarda Müslümanların bu toplulukla beraber yaşamak istemedikleri, Hz. Dâvûd'un onları lanetlemesi ile maymuna dönüştürüldükleri anlatılmaktadır. ${ }^{48}$

$\mathrm{Bu}$ kıssadan Bakara suresinde de özetle söz edilir: "İçinizden, Cumartesi günü (avlanma yasağı)nı çiğneyenleri elbette bilmişinizdir; işte onlara: "Aşağılık maymunlar olun!" dedik ve bunu önündekilere ve ardından geleceklere ibret bir ceza, (Allah'ın azabından) korunanlara da bir öğüt yaptık." (el-Bakara 2/65-66).

İsrailoğullarının dinî esasları çerçevesinde haftada altı gün günlük işlere ayrılıp çalıșllabilecek, yedinci gün ise Allah'a ayrılacaktı. Yedinci gün olan Cumartesi, ${ }^{49}$ kutsal sayılıp ibadetleri yapmaya tahsis edilecek ve o güne saygı gösterilecekti. Fakat toplumda ahlakî yozlaşma ortaya çıkınca bu kural çiğnenerek Cumartesi gününde iş yapar oldular. ${ }^{50}$

A'râf suresinin 163. âyetinde Hz. Peygamber'e hitaben "onlara sor" ve Bakara sûresinin 65. âyetinde "İçinizden Cumartesi günü (avlanma yasağı)nı çiğneyenleri elbette bilmişsinizdir," şeklinde geçen ifadelerden Yahudilerin bu kıssadan haberdar oldukları anlaşılmaktadır. Yahudiler bu kıssayı bilmemiş olsalardı Medine'de bu âyet nazil olduğunda şaşırıp kalır veya tepki verirlerdi. Oysa tefsir kaynaklarında tepki verdiklerine veya en azından şaşırdıklarına dair herhangi bir kayıt bulunmamaktadır. Üstelik ilgili âyette

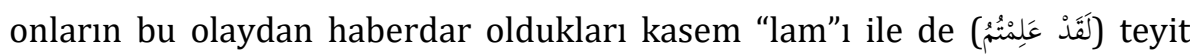
edilmektedir. ${ }^{51}$ Ayrıca bu ifadede geçen "kad" (قَ) edatı mazi bir fiilin

${ }^{48}$ Bk. İbn Kesir, Tefsîrü'l-Kur'âni'l-'Azîm, 1/105-107; Muhammed b. Yûsuf b. Ali b. Yûsuf b. Hayyan el-Endelusî Ebû Hayyan, el-Bahrü'l-muhît (Riyad: Mektebetü ve Metâbi'u'nNasri'l-Cideyșe, ts.), 1/346; Muhammed Ebü'l-Fazl el-Âlûsî, Rûhü'l-me'ânî fî tefsîri'lKur'âni'l-'Azîm ve's-seb'i'l-mesânî (Beyrut: Dâru İhyâi't-Türâsi'l-Arabî, ts.), 1/282.

49 Bir rivayete göre onlar da bizim gibi Cuma günü ibadet yapmakla sorumlu tutulmuşlardı; ancak, Cumayı bırakıp Cumartesi gününü seçtiler. (Bk. Taberî, Câmi' 'u'lbeyân fî Tefsîri'l-Kur'ân (Beyrût: Dârü'l-Ma'rife, 1407), 1/261; Âlûsî, Rûhü'l-me'ânî, 9/93. 50 Çılkıș 31/12-17. Ayrıca bk. Mevdûdî, Tefhîmü'l-Kur'ân,1/84; Vehbe Zuhaylî, et-Tefsîrü'lmünîr (Beyrut: Dârü'l-Fikri'l-Mu'âsır, 1411/1991), 1/181; Elmalılı M. Hamdi Yazır, Hak Dini Kur'ân Dili, sad. İsmail Karaçam vd. (İstanbul: Azim Dağıtım, ts.), 1/317.

51 Muhammed Reșid Riza, Tefsîrü'l-Kur'âni'l-'azîm (Tefsîrü'l-menâr) (Beyrût: Dârü'lKütubi'l-lilmiyye, 1420/1999), 9/316. 
öncesinde kullanıldığında fiilin kesin olarak yerine getirildiğini ifade eder.52

Âyetlerden anlaşılan o ki, söz konusu bu olay bizatihi gerçekleşmiş ve bunu müşahede edenler olmuştur. Kuşkusuz İsrailoğullarından bir grubun şahsında verilen ibret dersi hiç kimsenin Allah'a karşı kurnazlık yapmamaya yönelik belirtilen bir ikazdır. Bu ikazdan ders çlkarmayanlar gerek bu dünya hayatında gerekse ahirette rezil-rüsva olmuş bir vaziyette cezalandırılacaklardır. Bir başka ifadeyle Yüce Allah, Resûlullah ve Müslümanlara karşı eziklik hisseden Yahudilere Cumartesi iş yapmama yasağını delmekten dolayı maymuna çevrilen kendi milletlerinden bir topluluğu hatırlatarak kendilerinin de ataları gibi benzer durumlara düşebileceklerine dikkat çekmiştir. Bu özel sebep, nassın geneline teşmil edilmesinde bir engel teşkil etmez. Zira "Sebebin hususiyeti nassın umumiyetine engel değildir" kuralı Tefsir ilminin temel ilkelerinden birisi olarak kabul görmüştür. Bu hadiseden anlaşllan o ki, maymuna dönüşüm sadece tarihin belli uğrak noktalarında yaşanmış bir vakı olarak görülmemesi gerekir. İnsanların dini veya ahlakî değerlerden uzaklaştıkları dönemlerde benzeri aşağılık bir konuma dönüşümün gerçekleşme ihtimalinin sinyalini vermektedir.

Tarihe ibretlik bir vaka olarak geçen bu olayın Hz. Dâvûd (as) döneminde yaşandığ1 ${ }^{53}$ konusunda genel bir kanaatin olduğu görülmektedir. Zira "İsrailoğullarının nankörlerine Dâvûd ve Meryem oğlu Îsâ diliyle lanet edilmiştir." (el-Mâide 5/78) âyetinde belirtilen lanetin büyük olasıllıkla Hz. Dâvud'un yaptığı lanet olduğu akla gelmektedir.

Kur'ân âyetleri mesh hadisesinin yaşandığı yer konusunda bir bilgi vermemektedir. Bu konuda müfessirler olayın yaşandığı bölgeye ilişkin farklı fikirler ileri sürerler. Çoğu müfessire göre olayın geçtiği yer Kızıldeniz kenarında Medyen ile Tûr arasında yer alan "Eyle" şehridir. Bu bölgenin ayrica Medyen veya Medyen ile Aynuna arasında "Makna" adında bir yer olduğu da rivâyetler arasında geçer. ${ }^{54}$ Eyle şehri günümüzde "Akabe" şeklinde isimlendirilmiş olup Ürdün'ün denizle bağlantısı olan tek liman kentidir. ${ }^{55} \mathrm{Bu}$ şehir İsrailoğullarının ekonomik açıdan ileri safhada oldukları

52 Cevherî, "Kad", 2/522; Serdar Mutçalı, Arapça Türkçe Sözlük (İstanbul: Dağarcık Yayınları, 1995), 689.

53 Ali Makrizî, el-Mevấîz ve'l-i'tibâr bi zikri'l-hıtât ve'l-âsâr (Bulak: Y. y., 1270), 1/232; Yazır, Hak Dini Kur'ân Dili, 4/159; Reşid Rıza, Tefsîrü'l-menâr, 1/285.

54 Taberî, Câmi'u'l-beyân, 9/62; Ebû Abdullah Fahrüddîn Muhammed b. Ömer b. Hüseyin er-Râzî, et-Tefsîrü'l-kebîr (Beyrût: Dâru İhyâi't-Türâsi'l-Arabî, ts.), 15/36; Yakut Hamevî, Mu'cemü'l-buldân (Beyrut: Dârü'l-Fikr, 1995), 1/292.

55 Aynı zamanda bu şehir Maan ile doğusundaki Vâdilhisma'dan gelen yolların Vâdîism adlı yerleşim yerinden geçerek körfeze ulaşabilen bir bölgede kurulmuştur. Bu 
dönemlerde hatırı sayılır bir ticaret merkezi olup Hz. Süleyman (as) bu şehri Kızıldeniz'de bulunan deniz birlikleri için merkez liman yapmıştı. ${ }^{56}$ Ayrıca Hz. Dâvûd (as) zamanında Şam ve Mısır'dan deniz yolu ile gelen hacıların uğrak yeri olmuştu. ${ }^{57}$

Mesh hadisesi Yahudilerin kaynak kitaplarında zikredilmemiştir. Fakat Bakara ve A'râf suresinde anlatılan bu bölgenin, Kur'ân âyetlerinin nüzulü sırasında bilinen bir yerleşim yeri olduğu anlaşılmaktadır. Ayrıca Medine Yahudilerinin, Resûlullah'a (sav) cephe alma fırsatını genel olarak kaçırmadıkları halde söz konusu bilginin teyidi hususunda itiraz etmemiş/edememiş olmalari ${ }^{58}$ da bunu teyit etmektedir. Kaldı ki Kur'ân'da olayın gerçekleştiği yerin açıkça bildirilmemiş olması bir eksiklik olarak görülemez. Zira Kur'ân, bu ve benzeri vakaları tarih veya coğrafyanın dar cenderesine sokmadan evrensel bir düşünceyle ele alarak her daim gerçekleşebilecek bir vaka olduğunu öne çıkarmaktadır. Bu hadise Kur'ân'da tarihî bir bilgi aktarma amacına yönelik olarak anlatılmamaktadır. Dolayısıyla yaşandığı andaki olayın şahitleri için bu vaka nasıl bir ibret belgesi ise, vakayı görmeyen isyankârlar ve isyandan sakınan muttakiler için de açık bir ibrettir. Nitekim Kur'ân bu hususu "Önündekilere ve ardından geleceklere ibret bir ceza, (Allah'ın azabından) korunanlara da bir ögüt yaptık." (el-Bakara 2/66) ifadesiyle dile getirmektedir.

\section{Meshe Uğrayanların Akıbeti}

Meshe uğrayanların akıbetinin ne olduğu hususu irdelendiğinde söz konusu meselenin fiziken mi yoksa manen mi gerçekleştiğine dair bize ipuçları vereceği kanaatindeyiz. Bu kapsamda incelenen tefsir kaynakları, meshin fizikî olarak gerçekleştiğinin anlaşılmasına katkı sağlamaktadır.

İsrailoğullarına uygulanan yasak karşısında Eyle halkı üç gruba ayrılmıştı.

\section{a. Yasağa saygı duyanlar,}

geçit eskiden Akabetü'l-Eyle diye bilinirken kısaltılarak Akabe şeklini almıştır. (Bk. Mustafa L. Bilge, "Akabe", Türkiye Diyanet Vakfi İslâm Ansiklopedisi (İstanbul: TDV Yayınları, 1989), 2/209.) Burada geçen Vadîizm kalıbında yer alan "ism" (إثم), Eyle kasabası halkının Allah'ın koyduğu yasak karşısında suçlarına bir gönderme niteliği taşıdığı şeklinde ilginç bir anekdottan da yeri gelmişken söz edilebilir. (Nur Ahmet Kurban, "İslâm Kaynaklarına Göre Sebt Yahudilerinin Maymuna Dönüştürülmesi Meselesi", Marife Dergisi 13/1 (2013), 14.)

56 Mevdûdî, Tefhîmü'l-Kur'ân, 2/106.

57 Zekeriyya b. Muhammed Kazvinî, Âsârü'l-bilâd ve ahbârü'l-'ibâd (Beyrut: Dâru Sadr, ts.), 60.

58 Mevdûdî, Tefhîmü'l-Kur'ân, 2/106. 
b. Yasağa karşı gelenler,

c. Yasağa uymayanların durumlarını Allah'ın bildiği ve nasihate gerek olmadığını söyleyenler.

$\mathrm{Bu}$ gruplarda yer alanların ceza çekip çekmeyeceği Kur'ân'da şu şekilde ifade edilmektedir: "Allah'ın helak edeceği yahut şiddetli bir şekilde azap edeceği bir kavme ne diye öğüt veriyorsunuz?" dedi. Dediler ki: "Rabbinize mazeret (beyan edebilmek) için, bir de belki korunurlar diye (öğüt veriyoruz)" (el-A'râf 7/164) ifadeleriyle birinci grubun cezadan muaf tutulduğu ve yasağ çiğneyen ikinci grubun cezalandırılacağı hususu da âyette "Ne zaman ki onlar, kendilerine hatırlatılanı unuttular, biz de kötülükten menedenleri kurtardık; zulmedenleri de yoldan çıkmaları yüzünden çetin bir azap ile yakaladık." (el-A'râf 7/165) şeklinde açıklığa kavuşturulmaktadır.

Bazı müfessirler tarafsız kalan üçüncü grubun kurtuluşa eren kişilerden mi, yoksa cezalandırılanlardan mı olduklarının kesin olarak bilinemeyeceğini ifade ederken; bazısı da bu grubun cezalandırılanlar arasında yer alması gerektiğini belirtmektedirler. ${ }^{59}$

Meshi ahlakî/ruhsal boyutta düşünenlere göre, olaya maruz kalanların neslinin devam edip etmediğine dair problem gözükmemektedir. Zira meshe maruz kalanların biyolojik yapılarında bir değişiklik meydana gelmediğine göre nesillerinin devam etmesine zarar verecek bir durum söz konusu değildir. Ne var ki, burada biyolojik yapılarında meydana gelen değişiklik nedeniyle fiziki olarak maymuna dönüșen Cumartesi ashabının soylarının devam edip etmediği sorusu da zihinleri epeyce meşgul etmiştir. Tefsir kaynaklarına göre bu cezaya çarptırılan grubun nesli devam etmemiştir. Onlar ne yiyip ne içmişler, üç gün boyunca maymun kılığında kalıp diğer insanlar onların bu vaziyetlerine şahit olmuş, daha sonradan da ölmüşlerdir. ${ }^{60}$ Bir rivayete göre hayvanların iki süt sağımı zaman dilimindeki süre boyunca maymun olarak yaşamış, sonra ölmüşlerdir. ${ }^{61}$ Başka bir rivayete göre de yedi gün yaşamış sekizinci gün ölmüşlerdir. ${ }^{62} \mathrm{Bu}$ rivayetler arasında bir bilgi daha vardır ki, o da maymuna çevrilme hadisesinin kişilerin yaşına göre değiştiğini, gençlerinin maymun, ihtiyarlarının domuz olduğunu

59 Taberî, Câmi'u'l-beyân, 9/63-64; İbn Kesir, Tefsîrü'l-Kur'âni'l-'Azîm, 2/257; Ebû Abdullah Muhammed b. Ahmed el-Ensârî el-Kurtûbî, el-Câmi' li ahkâmi'l-Kur'ân (Beyrut: Dârü'l-Kâtibi'l-Arabî, 1387/1967), 7/307.

60 Taberî, Câmi'u'l-beyân, 1/261, 2/168; İbn Kesir, Tefsîrü'l-Kur'âni'l-'Azîm, 2/258; Kurtûbî, el-Câmi' li ahkâmi'l-Kur'ân, 1/440-441; Âlûsî, Rûhü'l-me'ânî, 1/283.

61 İbn Kesir, Tefsîrü'l-Kur'âni'l-'Azîm, 2/368.

62 Âlûsî, Rûhü'l-me'ânî, 1/283. 
bildirmektedir. 63

Hem Bakara sûresi 66. âyette hem de A'râf suresi 166. âyette kullanılan "aşağıllı" anlamına gelen "hasiîn" (خَاسئِين) kelimesi tefsir kaynaklarında şu iki hususta değerlendirilmektedir:

a. "Hasiîn" kelimesi, "kırade" (قِرََّ) (maymunlar) kelimesinin sıfatıdır. Bu duruma göre anlamı "aşağılık" maymunlar olur.

b. Bu kelime, "kırade" (مِرِدَ) kelimesine sıfat değil, İsrailoğullarına gönderme yapan "kûnû" (كونُوا) fiilinin ismi olan "vav" zamirine haldir. Bu duruma göre de âyetin anlamı "aşağılanmış olarak maymun olun" șeklinde olur.64 Zemahşerî, (ö. 538/1144) Beyzâvî (ö. 685/1286) de "kırade" (قِرَّدَ) ve

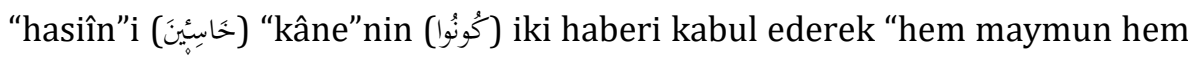
aşağılanmış mahlûk olun" diyerek farklı bir yaklaşım sergilemişlerdir. ${ }^{65} \mathrm{Bu}$ ifade meâllerde genellikle "aşağılık maymunlar" olarak kullanılmıştır. Bize göre ikinci mananın kullanılması daha tercihe şayan görünmektedir. Zira Yüce Allah'ın belli bir amaca yönelik yarattı̆̆ hiçbir varlık "aşağılık" konumunda olamaz.

Allah bu şekil değişikliğinin fecaatini vurgulayarak meshin sadece maymuna dönüştürme konusu kapsamında olmadığını, bazılarının siret veya suretlerini domuz kılığına dönüştürdügünü de bildirmektedir. Burada domuza çevrilenlerin kimliği konusunda farklı görüşler vardır. Zira yukarıda verilen farklı rivayetlerden yola çıkarak kimi müfessirler yasağı çiğneyenlerden yaşlı olanların domuza, gençlerinin maymuna; kimi müfessirler ise yasağı çiğneyenlerin maymuna, Hz. Îsâ'nın mucizesi olan sofrayı inkâr edenlerin domuza çevrildiklerini ${ }^{66}$ ifade etmektedirler.67

63 Taberî, Câmi'u'l-beyân, 9/66; Zemahșerî, el-Keșşâf, 2/127; Râzî, et-Tefsîrü'l-kebîr, 3/111; Makrizî, el-Mevâ 'îz, 1/185; Yazır, Hak Dini Kur'ân Dili, 3/275.

${ }^{64}$ Krș. Ebû Muhammed Hüseyin b. Mesud el-Begavî, Me'âlimü't-tenzîl (Y. y.: Dâru Tayyibe li'n-Neşr, 1997), 1/105; Âlûsî, Rûhü'l-me’ânî, 1/283.

65 Zemahşerî, el-Keşşâf, 1/147; Abdullah b. Ömer b. Muhammed Beyzâvî, Envârü't-tenzîl ve esrârü't-te'vîl (Mısır: Matba'atu Mustafa Muhammed, ts.), 1/213.

66 Taberî, Câmi'u'l-beyân, 9/64; Zemahșerî, el-Keşşâf, 1/626; Râzî, et-Tefsîrü'l-kebîr, 3/112; Beyzâvî, Envârü't-tenzîl, 2/159.

${ }^{67}$ Kur'ân'da meshe uğrayanların maymun ve domuza dönüştürülmesinden bahsedilirken aynı vaka ile ilgili bazı hadislerde onların fare, keler, kertenkele gibi hayvanlara çevrildiğinden de söz edilmiştir. (Buhârî, el-Câmi'u's-sahîh; Ebü'l-Hüseyn Müslim b. elHaccâc Müslim, el-Câmi'u's-sahîh (İstanbul: Çağrı Yayınları, 1981) "Sayd", 48, 50, "Zühd", 62.) Bu hadislerde söz konusu olayın şeklen gerçekleştiği yönündedir. (bk. Muhammed Fatih Kesler, “Kur'ân-ı Kerim'de Tarihsel Bir Gönderme (İnsanın Maymunlaşması ya da Kimlik Kaybı”, Diyanet İlmî Dergi 51/4 (2015), 116. 
Bakara sûresinde ashâb-ı sebt hakkında sadece "aşağılık maymunlar olun!" denirken, domuz ifadesinin kullanılmamış olması maymun ve domuz olanların farklı bir grup olması daha muhtemel görünmektedir. 68

Ayrıca hem Hz. Dâvûd hem de Hz. Îsâ'nın diliyle İsrailoğullarının lanetlenmiş olması durumu ${ }^{69}$ bu olaylarla alakalı ise -ki öyle olduğu anlaşılmaktadır- maymuna ve domuza çevrilenlerin farklı zamanlarda yaşamış iki ayrı grup olma ihtimalini güçlendirmektedir. Kaldı ki, Hz. Îsâ'nın daha önceki devirlerde yaşayıp da Allah'ın kendileri için koyduğu yasağı çiğneyenlere lanet okuması mantıkî açıdan da uygun düşmemektedir.

Allah Hz. Îsâ aracıllğıyla gökten sofra talebinde bulunanların isteklerini yerine getirmiş, ancak bu vakadan sonra yine de inkâra kalkışacaklarını ve bu nedenle daha önce benzeri görülmemiş bir cezaya çarptırılacaklarını bildirmiştir. ${ }^{70}$ Son âyette bu kişilerin sofrayı inkâr etmiş olmalarından dolayı ağır cezaya çarptırıldıkları aynı surenin 60. âyetinin delaletiyle anlaşılmaktadır.

\section{Dönüşümün Fiziksel Mi Yoksa Manevî Mi Olduğu Meselesi}

Kur'ân'ın farklı surelerinde birkaç kez üzerinde durulan mesh hadisesinin söz konusu insanların bedenlerinde meydana gelen bir şekil değişikliği veya ahlakî yönden bir bozukluğu ifade edip etmediği konusu müfessirler arasında önemli bir tartışma olarak yer almaktadır. Müfessirlerin büyük çoğunluğu meshin fiziksel olarak gerçekleştiğini savunurken, ilk dönem müfessirlerden biri olan Mücâhid b. Cebr ${ }^{71}$ (ö. 103/721) ve özellikle son dönemde onun düşüncesi etrafında görüşlerini şekillendirmiş olan bazı müfessirler, meshin fiziksel değil manevî/ruhsal yönden bir dönüşüm olduğunu iddia etmektedirler. ${ }^{72}$

Meshin fiziksel olarak gerçekleștiğini düşünen müfessirler nassın

${ }^{68}$ Râzî, et-Tefsîrü'l-kebîr, 15/42; Yazır, Hak Dini Kur'ân Dili, 3/275.

${ }^{69}$ el-Mâide 5/78.

70 el-Mâide 5/112-115.

71 Tabiîn döneminin önde gelen müfessirlerinden biri olarak kabul edilmektedir. Onun, meshin manevî olarak gerçekleştiği şeklinde ortaya attığı görüşünü sahabe, tabiîn ve daha sonraki klasik dönem âlimler arasında benimseyenler pek olmamıștır. Öyle ki, milâdî XIII. asırda yaşamış olan müfessir Kurtûbî (öl. 671/1258) Mücâhid'in görüşüne paralel başka hiç kimsensin görüşüne rastlamadığını ifade etmektedir. (Bk. Kurtûbî, el-Câmi' li ahkâmi'lKur'ân, 1/441.) Fahreddin er-Râzî, (öl. 606/1210) Mücâhid'in görüşünün olabilirliğine kapı aralasa da söz konusu mesh hadisesinin fiziksel olarak gerçekleştiği görüşünü daha isabetli bulmaktadır. (Râzî, et-Tefsîrü'l-kebîr, 3/111.)

72 Ebü'l-Haccâc Mücahid b. Cebr, Tefsiru Mücahid, thk. Abdurrahman et-Tahir b. Muhammed (Beyrut: el-Menșûrâtü'l-İlmiyye, ts.), 1/77; İbn Kesir, Tefsîrü'l-Kur'âni'l-'Azîm, 1/105-106; Âlûsî, Rûhü'l-me'ânî, 1/283; Yazır, Hak Dini Kur'ân Dili, 1/378; Sadık Kılıç, Kur'ân'da Günah Kavramı (Konya: Hibaș Yayınları, 1984), 351-352. 
zahirî anlamının öncelikle tercih edilmesi gerektiği görüşünü dikkate almaktadırlar. Oysa genel olarak nassın zahirinde bir kapalılık olması durumunda mecazî anlamın tercih edilmesi gerektiğini müfessirler ifade etmektedirler. Mesh hadisesinde de bu kural işletilerek âyetlerin mecaz olabilecek bir tarafının bulunmadığı görüşüne varmakta ve sözü edilen mesh olayının hem suret hem de sireten (ahlak, hal, karakter) değişikliği doğuran bir dönüşüm olduğu kabul edilmektedir. Buna karşın bazı yorumcular meshin temsili olduğunu düşünmekte, dönüşümün niteliğini yorumlayarak ve olayı aklileştirerek benzetme yoluyla tasvir edilmiş olduğunu söylemektedirler. Onlara göre Allah, yasağa uymayanların maymun gibi olmalarına hükmetmiş, belirtilen dönemden itibaren, maymunların davranışlarına benzer davranmaya başlamışlardır. Kendilerinin karakterleri, maymunların karakterlerine benzemiştir. ${ }^{73}$ İsrailoğullarının karakter yönüyle mesh edildiklerini iddia edenler, "Kendilerine Tevrat yükletilip de sonra onu taşımayan (onun buyruklarını, tutmayan)ların durumu, kitaplar taşıyan eșeğin durumu gibidir" (el-Cuma 62/5) âyetindeki benzetmeyi aynı metotla meshe de örnek göstererek onların maymun gibi olduklarını kastetmişlerdir. ${ }^{74} \mathrm{Bu}$ âyette İsrailoğullarının Tevrat'ın âyetleriyle amel etmeleri istenmesine rağmen bu sorumluluğun bilincinde olmadıklarına dair dikkat çekici bir benzetme yapılmıştır. Zira eşekler de yüklendikleri bilgi dolu kitaplardan istifade edemezler, amaçsız o ağırlığın hamallığını yaparlar. Üzerlerinde taşıdıkları yükün kitap olduğunun farkında değildirler. Yahudilerin Tevrat'ı yüklenmesi aynen bir eşeğin kitapları taşımasına benzerdir. Allah'ın mesajlarına uymayıp onları inkâr edenler burada eşeğe benzetilmiştir. Çünkü eşekler bilinç sahibi varlıklar değildir. Oysa burada üzerinde konuşulan insanlar anlama yeteneğine sahip varlıklardır. ${ }^{75}$ Benzer örneklendirme A'râf suresinde de yer almaktadır. Bu surede Allah'ın hükümlerini kabul etmeyenler, kendisine ilişilsin ya da ilişilmesin sürekli dilini sarkıtıp soluyan köpeğe benzetilmiştir. ${ }^{76}$ Oysa mesh vakasında bu örneklere benzer bir benzetme yapılmadığı gibi belagat ilminin temel unsurlarından olan benzeyenle benzetilen arasında olması gereken benzetme edatı da kullanılmamıștır. Dahası bu vakada benzetme yerine

\footnotetext{
73 Abdurrahman Kasapoğlu, “Kur'ân'da Hayvan Davranışlarına Benzetilen İnsan Karakterleri”, Firat Üniversitesi İlahiyat Fakültesi Dergisi 11/1 (2006), 53.

74 Râzî, et-Tefsîrü'l-kebîr, 3/111; İbn Kesir, Tefsîrü'l-Kur'âni'l-'Azîm, 1/105.

75 Kasapoğlu, "Kur'ân'da Hayvan Davranışlarına Benzetilen İnsan Karakterleri”, 59.

76 el-A'râf 7/176. Bir başka örnek de Ankebût suresinin 41. âyetinde yer alır. Bu âyette Allah'tan başkasını dost edinenler, yıkılması çok basit olan örümceğin evine benzetilmiștir.
} 
doğrudan tekvinî emir kalıbında "olunuz" (كُونُوانو 77 ifadesi yer almıştır.

Maymuna dönüştürme vakasının fiziksel olarak gerçekleştiğini kabul edenler arasında maymuna çevrilenlerin aklî melekelerinin hangi durumda olduğuna dair düşünceler de gündeme gelmektedir. Bazı âlimler bu olayın sadece fiziksel bir dönüşüm olduğunu, insanî değerlerinin, bilinç ve aklî kuvvelerinin ise baki kaldığını ifade etmektedirler. ${ }^{78}$

Meshin manevî değil de fiziksel olarak gerçekleştiğinin delillerinden birisi de aslında kendilerine ağır bir şekilde azap edilecek olmasının ya da helak edilecek bir topluluğa nasihatte bulunmanın bir yarar sağlamayacağının A'râf suresinde belirtilmiş olmasıdır. ${ }^{79}$ Zira değişimin fiziksel dönüşüm yerine sadece karakter değişikliği olması durumunda âyette "helak edilme" sözüne hiç gerek kalmayacağı aşikârdır. Dolayısıyla bu derece ağır bir cezalandırmanın sadece manevî olarak gerçekleştiğini ifade etmenin âyetin ruhuna aykırı düștügü rahatlıkla söylenebilir.

Kur'ân'da cezalandırılan kavimlere bakıldığında iman etmeyi, elçilerden olağanüstü işler yapmalarına bağlayan pek çok topluluğun mucizeler yaşamasına rağmen iman etmemekte diretmeleri nedeniyle helak edildikleri görülmektedir. Bu tür cezalandırma örnekleri şunu gösteriyor ki Allah, gerekli uyarıları yaptığı halde bu uyarılara kulak tıkayan bazı toplulukları yok etme, ${ }^{80}$ yerin dibine batırma, ${ }^{81}$ üzerlerine taş yağdırma ${ }^{82}$ suretiyle cezalandırmıştır. Bu vakaların bazılarında mucizevî bir şekilde fizikî kuralların aksine aklen izahı kolay olmayacak derecede (fil vakası gibi) uygulamalar gerçekleştirilmiştir. $\mathrm{Bu}$ bağlamda avlanma yasağını çiğneyenlerin maymuna veya domuza çevrilmesi suretiyle cezalandırılmasının da aynı şekilde insanları caydırıcı etkinlikte olabilmesi için şeklen bir değişikliğin olması mantığa daha uygun düşmektedir.

Kelam ilmi açısından da meseleye bakılacak olursa, söz konusu bu ilmin varlık anlayışı açısından mesh meselesinin imkânsızlığından bahsedilemez. Zira bu ilmin sunduğu varlık anlayışına göre, Allah'tan başka bütün varlıklar hadis ve mümkündür. Evrende var olan hiçbir varlık zorunlu olmadığı gibi ezelî ve ebedî bir özelliğe sahip değildir. Bu özellikler sadece Allah'a aittir. Varlığı zorunlu ve değişmeyen tek varlık Allah'tır. O'nun

77 el-Bakara 2/65; el-A'râf 7/166.

78 Râzî, et-Tefsîrü'l-kebîr, 3/111; Mevdûdî, Tefhîmü'l-Kur'ân, 1/84.

79 el-A'râf $7 / 164$

80 İbrâhim 14/19-20; et-Tevbe 9/39.

81 en-Necm 53/53; et-Tevbe 9/70; el-Hâkka 69/9.

82 el-Hicr 15/74; el-Ankebût 29/40; Hûd 11/82. 
dışındaki varlıkların, Allah tarafından yoktan var edilerek istediği hale sokulması, farklı varlıklara dönüştürülmesi veya yok edilmesi O'nun gücü dâhilindedir. Aynı şekilde insan da Allah tarafından yoktan var edilen bir varlık olduğuna göre onu da gerektiğinde başka bir varlık türüne dönüştürülebilir. ${ }^{83}$

\section{Meshe Uğrayanların Sayısı}

Mesh hadisesine ilişkin en dikkat çekici ve insanda merak uyandıran noktalardan birisi "Eyle" denen bu şehirde yasağı çiğnedikleri için meshe maruz kalan insanların sayısıdır. Elbette asırlar öncesinde yaşanan bir vakaya muhatap olanların sayısını tam olarak belirtmek oldukça zordur. Ancak tefsir kaynaklarında geçen ifadelerden meshe uğrayanların sayısını yaklaşık olarak vermek mümkündür. Bu konuya geçmeden önce Kur'ân'da belirtilen "karye" kavramının aydınlatılması yararlı olacaktır.

"Karye" ifadesi sözlük karşılığı olarak köy, küçük kasaba ve taşra semti gibi anlamlara gelirken, ${ }^{84}$ terim olarak çoğunlukla şehir anlamında kullanılmaktadır. Kur'ân'da "karye" ifadesinin geçtiği âyetlerin mefhumundan "köy" yerine daha çok "şehir" veya "kent" anlamında kullanıldığını görmek mümkündür. 85

Eyle şehrinin, İsrailoğullarının parlak dönemlerinde merkezi bir durumda olması ve $\mathrm{Hz}$. Süleyman'ın bu yerleşim yerinin limanını Kızıldeniz' deki donanması için merkez liman yapması ${ }^{86}$ bu yerleşim yerinin dönemin kentleri arasında merkezî bir kent hüviyetinde, dolayısıyla nüfusunun hiç de azımsanmayacak bir yoğunluğa sahip olduğunu göstermektedir.

Bazı kaynaklara göre, Eyle'nin nüfusu yaklaşık 70 bindir. ${ }^{87}$ Yukarıda da ifade edildiği üzere şehir halkından avlanma yasağını çiğneyenler, yasağa uygun hareket edip yasağı çiğneyenleri uyaranlar ve yasağı çiğnemeyip yanlış yapanları uyarmanın bir fayda sağlamayacağını söyleyenler olmak üzere şehir halkı üç gruba ayrılmıştı. Eyle nüfusunun yaklaşık 70 bin civarında olduğunu kaydeden kaynaklar, yasağa uyup yasağı delenleri

83 Tevfik Yücedağ, "Kur'ân ve Mesh”, Uludağ Üniversitesi İlahiyat Fakültesi Dergisi 20/2 (ts.), 70-71.

84 Ahmed Muhtar Ömer, el-Mu'cemu'l-mevsu'a lielfâzi'i-Kur'âni'l-Kerîm ve kıra'atuhu (Riyad: Müessesetü Sütûri'l-Ma'rife, 1423), 370-371; Mutçalı, "Karye”, 703.

85 İlgili âyetler için bk. el-A'râf 7/88; el-Enbiyâ 21/11; Hûd 11/100; eş-Şûrâ 42/7.

86 Mevdûdî, Tefhîmü'l-Kur'ân, 2/106.

87 Begavî, Me'âlimü't-tenzîl, 3/293; Kazvinî, Âsârü'l-bilâd ve ahbârü'l-'ibâd, 60; Âlûsî, Rûhü'l-me'ânî, 6/409. 
yaptıkları yanlış eylemden dolayı sakındıranların sayısını da 12 bin ${ }^{88}$ olarak verirken; yasağı çiğnediklerinden dolayı helake maruz kalanların sayısı konusunda hiçbir rakam sunmamışlardır.

Diğer taraftan müfessirlerin kahır ekseriyeti bazı Hıristiyanların Hz. Îsâ'dan gökten bir sofra/mâide indirilmesi isteklerine karşı gösterdikleri aymaz tavırları yüzünden domuza çevrilenlerin sayısını da aralarında kadın ve çocukların bulunmadığı 5 bin kişi ${ }^{89}$ olarak vermektedir.

Aslında tefsir kaynaklarında meshe uğrayanlarının sayısına ilişkin verilen rakamlar da söz konusu vakanın zahiren gerçekleştiğine dair bir başka kanıt olarak sunulabilir. Zira rakamların telaffuz edilmesi müşahede edilen somut veriler üzerinden yapılmaktadır. Aksine bu vaka manevi olarak gerçekleşmiş olsaydı cezaya çarptırılanların sayısı bilinemeyeceğine göre, müfessirler açısından farklı rakamlar telaffuz edilse de olayın somut olarak gerçekleştiği yönünde güçlü veri olarak sayılmalıdır.

\section{4. "Mesh"in Âyet Bağlamı ve İlgili Ayetlerde Geçen Kavramlar Açısından Değerlendirilmesi}

Mesh olayının Kur'an'da anlatılan ayetlerde meshin fiziksel olarak yaşanmışlığı konusunda yaptıkları katkıya geçmeden önce söz konusu vakanın fiziksel/biyolojik veya ruhsal/manevî yönden gerçekleşmiş olduğuna dair ifade edilen farklı görüşler bağlamında bir değerlendirme yapmak gerekirse şu hususlara değinmek yerinde olacaktır.

1. Yüce Allah'ın defalarca uyardığı, ancak tamamına yakınında uyarılara kulak asmadıkları anlaşılan İsrailoğullarına Cumartesi günü yapılmaması gereken bazı yasaklar koymuş, hatta bu konuda kendilerinden kesin söz alınmasına rağmen yasağa uygun davranmayan Eyle halkına unutulmayacak ağır bir ceza uygulanmıştır. Üstelik bu topluluk Allah'a söz verirken sözlerini teyit edecek mahiyette kesinlik ifade eden kelimeler kullanmışlardı. "Söz vermeleri için Tûr'u üzerlerine kaldırdık ve onlara 'secde ederek kapıdan girin' dedik ve onlara: 'Cumartesi (yasakları)nı çiğnemeyin' dedik ve onlardan sağlam bir söz aldık.” (en-Nisâ 4/154). Açıkça söz vermelerine rağmen yaratıcıya başkaldırmanın cezası sadece basitçe sözlü aşağılama ifadesi ile geçiştirilecek bir ceza olmadığını düşünüyoruz. Doğrusu her toplumda yaşanabilecek benzeri bir ahlakî çöküşün, ibret levhası olarak yıllar sonra insanların kıssadan hisse çıkarabilecek türden önemi haiz

88 Begavî, Me'âlimü't-tenzîl, 1/105.

89 Râzî, et-Tefsîrü'l-kebîr, 6/129; Beyzâvî, Envârü't-tenzîl, 2/159; Âlûsî, Rûhü'l-me'ânî, $5 / 95$. 
olduğunu ifade etmek mantıklı görünmemektedir.

Yüzyıllar boyunca konuşulacak bir olayın gözle görüldüğünde insanı dehşete düşüren ve hafızalara kazınan bir görüntünün yıllar sonra anlatıldığında muhataplarını etkileyebilecek cinsten bir ceza olması gerektiği daha mantıklıdır. Görsel materyallerin olmaması yaşanan olayların etkinliğini azaltacağı bir hakikattir. Söz konusu meshe uğramış insanlarda da mutlaka buna benzer şekil değişikliği veya hem şekil hem de karakter değişikliği meydana gelmiş olmalı ki insanlar nezdinde yansımaları etkili bir şekilde görülmüş olsun. Fiziksel/biyolojik yapısında hiçbir değişiklik meydana gelmeyen insanların dişarıdan bakıldığında maymun olup olmadıkları anlaşılamaz. Bu itibarla sadece karakter değişikliğiyle kimlik değişikliğinin oluştuğunu söylemek iddialı bir çıkış olacağı izahtan varestedir. İnsanların gözünde böyle bir çarpıcı durumun görüntülerinin alenen görülebilir bir surette olması gerekir ki, söz konusu bu durumun başkaları nezdinde bir caydırıcılık özelliği taşımış olsun. Ayrıca yukarıda da kısaca değinildiği gibi bu insanların kapılarını dış dünyaya kapattıkları düşünüldügünde hiç kimsenin böyle bir olayın yaşanmış olduğunun bile farkına varması mümkün olmayacaktır.

Bu olayın anlatıldığı sûrelerdeki âyetlerin bağlam kurgusu da meshin fiziksel olarak gerçekleştiğine işaret etmektedir. ${ }^{90}$ Nitekim A'râf 163 ve 165.

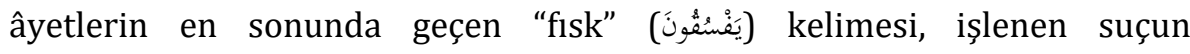
büyüklügünün tespitinde yardımcı olmaktadır. Çünkü Kur'ân'da "fısk" kavramı daha çok insanı cehenneme sürükleyen eylemlerde kullanılmıştır. Nitekim Firavun ve yandaşlarının, Nûh (as) kavminin helakle son bulan amellerinde de bu kavram ${ }^{91}$ kullanılmaktadır. Benzer şekilde olayın anlatıldığı Bakara suresinin 65. âyetinden sonraki 66. âyette de bağlamın önemi bir kez daha ortaya çıkmaktadır. Burada da " "Hem çağdaşlarına hem de sonradan gelenlere ibret veren bir ceza" olduğu açıkça belirtilmekte ve bunun gibi suçların işlenmesinde caydırıcılık vasfı öne çıkarılmaktadır.

"Nekâl" ifadesinin de Kur'ân'da geçtiği yerlere bakıldığında daha çok ağır suçlar ve bunlara verilen cezalardan caydırmaya yönelik önemli uyarıların yapıldığı konularda kullanıldığı görülmektedir. Bu örneklerden birisi hırsızlık yapana uygulanacak el kesme cezasında92; bir diğeri Hz.

90 Mevlüt Erten, “Kur'ân'da Hakikat ve Mecazın Tespitinde Bağlamın Önemi”, İslâmî Illimler Dergisi 8/1 (2013), 174.

91 el-Bakara 2/59; el-İsrâ 17/16-17.

92 el-Mâide 5/38. 
Peygamber ve inananların savaşa teşvik edilmesi ile ilgili âyet bağlamında Allah'ın kâfirlere karşı cezasının çok güçlü olduğunun hatırlatılmasında93 geçmektedir. Hırsızlık yaptığında gerçekten eli kesilmeyen birisinin insanlara ibret olması nasıl imkân dâhilinde değilse, benzer şekilde şeklen maymuna çevrilmemiş bir kişinin de insanlığa ibret olması düşünülemez. Kısaca ifade etmek gerekirse "nekâl" (نَخَا) ifadesi insanları benzeri bir suça bulaşmaktan engelleyen etkili bir cezadır. ${ }^{94}$ Ayrıca Kâdî Abdülcebbar (ö. 415/1025) cezaya ancak etkili veya büyüklüğü halinde "nekâl" denebileceğini belirtmektedir. 95 "Nekâl" ifadesinin bu şekildeki delaletiyle mesh hadisesinin somut bir olay olarak yaşanmışlığına delalet etmektedir. Zira insanları buna benzer bir günah işlemekten alıkoyan büyük bir karşılık ancak bu şekilde olur. ${ }^{96}$ Kaldı ki, eğer fiziksel bir ceza yerine sadece hakaret edilmiş olsaydı gerçek anlamda ne bir ceza verilmiş olacaktı ne de caydırıcılık vasfı bulunacaktı. Oysa "nekâl" ifadesi işlenen bir suçun büyüklüğüne göre bir karşıllk verilmesini ifade eder.

Diğer taraftan, bazı Yahudi kabilelerinin “İsrailoğullarının Allah'a karşı bir isyanı söz konusu olmamış, emredildikleri şeyler konusunda da herhangi bir direnç göstermemişlerdir," şeklindeki sözlerine karşılık onların iddialarını çürütmek, yalanlarını ifşa etmek ve atalarının maruz kaldığı mesh vakasını onlara hatırlatmak üzere âyetin nazil olduğ ${ }^{97}$ kabul edilecek olursa, bu olayın gerçekten tarihe mal olmuş bir olay olduğu rahatlıkla söylenebilir. Eğer sadece onları yermek ve aşağılamak için söylenmiş bir ifade olmuş olsaydı tekraren bu vakanın hatırlatılmasına gerek kalmayabilirdi.

2. Şayet sadece ahlakî veya ruhsal bir dönüşüm kastedilmiş olsaydı âyette de ifade edildiği gibi- söz konusu olayın ibret-i âlem olması için üzerinde bu kadar vurgu yapılmasına gerek kalmayabilirdi. Öyle ki her dönemde ahlakî çöküntü içerisine giren ve gerçekleştirdikleri eylemler itibariyle maymuna benzeyen insanlar olmuştur, şu anda da olmaktadır ve bundan sonra da olacağında bir kuşku yoktur. Ayrıca şunu da belirtmek gerekirse, Yüce Yaratıcının meshi tüm âleme, "Bunu, önündekilere ve ardından geleceklere ibret bir ceza yaptık" ifadesiyle bir vaka olarak

93 en-Nisâ, 4/84. Bu âyette "nekâl" yerine "tenkîlâ" (تَنْكيلاً ifadesi kullanılmıștır.

94 İsfahânî, "nkl”, 824-825; Muhammed et-Tahir İbn Âşûr, et-Tahrîr ve't-tenvîr (Tûnus: Dârü't-Tunusiyye, 1984), 1/546.

95 Râzî, et-Tefsîrü'l-kebîr, 3/112.

96 Kurban, "İslâm Kaynaklarına Göre Sebt Yahudilerinin Maymuna Dönüștürülmesi Meselesi", 22.

${ }_{97}$ A'râf suresinin 163. âyeti bağlamında nazil olduğu belirtilmektedir. Bk. Ebû Hayyan, el- 
sunmasının; meshin, manevî dönüşümün ötesinde şeklen gerçekleştiği yönünde tam bir karine olduğu rahatlıkla ifade edilebilir. Sonraki nesiller için caydırıcı olabilecek bir vakanın somut yansımalarının olması gerekir ki o olaydan ders çıkarılabilsin. Tıpkı ilahlığını ilan eden, Hz. Mûsâ ile mücadele eden ve ilahî mesajlara ayak direten Firavun'un denizde (Kızıldeniz) boğulması gibi. ${ }^{98}$ Kesin bir bilgi olmamakla birlikte secde eder vaziyette bulunan Firavun'a ait cesedin bugün hala nasıl insanlara ibretlik ders veriyorsa cesetleri ortalıkta bulunmasa da maymuna dönüştürülen insanların en azından ibretlik hikâyeleri insanları aynı şekilde etkilemektedir.

3. Meshi bir karakter değişimi olarak kabul edip görüşlerini mantıkî bir zemine oturtmaya çalışanlar, Cuma suresi 5 . âyette ifade edilen kendilerine Tevrat yükletilip de içeriğine layık hareket etmeyenlerin kitap taşıyan eşeğin durumuna benzetilmesini delil kabul ederler. ${ }^{99}$ Oysa bu âyette bir vakanın tanıtımı değil "kemeseli" (كَمَثَّل) (gibidir) ifadesiyle benzetme yapılarak teşbihte bulunulmaktadır.100 Aynı benzetme "Onlar hayvanlar gibidir, hatta onlar, yolca (hayvanlardan) daha sapıktır." (el-Furkân 25/44) ve "Isste onlar hayvanlar gibidir, hatta daha da sapık." (el-A'râf 7/179) âyetlerinde de yapılmaktadır. Bu âyetlerdeki ifadelere dikkat edilecek olursa hep "ke" (gibi) (ke'l-en'âm: hayvanlar gibi) edatlar kullanılırken, mesh olayının anlatıldığı âyetlerde ise maymuna dönüşümün gerçekleşmesine yönelik emir sığasıyla "kûnû" (olun) șeklinde kevnî bir ifade yer almaktadır. Dolayısıyla bu konu Muhammed Esed'in (ö. 1992) "Bu, Allah'ın, onların durumunu tasvir etmek için irad ettiği bir mesel, bir benzetmeden başka bir şey değildir, ${ }^{\prime 101}$ dediği kadar da kesin ifadelerle hüküm bina edilecek cinsten bir mesele olmadığı da rahatlıkla ifade edilebilir.

Diğer taraftan yüce Allah'ın Kitap ehli Yahudilere yönelik hitabında Kur'ân'a inanmaları istenmekte, aksi takdirde suratlarında bir takım fiziksel değişikliklerin yapılacağından söz edilmektedir: "Ey Kitap verilenler, biz bazı yüzleri silip arkalarına döndürmeden ya da Cumartesi adamlarını lanetlediğimiz gibi onları da lanetlemeden önce yanınızdakini doğrulayıcı olarak indirdiğimiz (Kur'ân)'a inanın. Allah'ın buyruğu yapılır." (en-Nisâ 4/47). Âyette geçen "lanetlenme" ifadesinin tefsir kaynaklarında çoğunlukla

98 Yûnus 10/92.

99 Esed, Kur'ân Mesajı, 307-308.

100 Benzer benzetmeler: "Kim Allah'a ortak koşarsa, o, sanki gökten düşmüş de kendisini kuş kapıyor veya rüzgâr onu, uzak bir yere sürüklüyor gibidir." (el-Hac 22/31.) "Allah'tan başka veliler edinenler bir ev edinen örümceğe benzerler." (el-Ankebût 29/41.)

101 Esed, Kur'ân Mesajı, 308. 
mesh vakası olduğuna dair yorumların aslında maymuna dönüştürme olayının fiziksel olduğuna işaret etmektedir ki, aksi durumda sadece manevî olarak "maymun olun" ifadesinin lanetlenmenin karşılığı olmayacağı açıktır.

Âyette geçen "tams" (طمس) bir şeyin izlerini yok etmek, alametlerini gidermek anlamına gelir.102 Yüzün tams edilmesi, görüntünün tamamen değişip yüz denecek halinin kalmaması anlamına gelir. Müfessirlerden bazıları, bu kelime ile İsrailoğullarından bir grubun suratlarının değiştirilip devetabanı, hayvan tırnağı şekline veya maymun suratına dönüştürüleceğini anlamışlardır. ${ }^{103}$

Kısaca Sebt ashabının Allah'ın emrine açıktan muhalefet etmeleri nedeniyle karşılığında etkili ve caydırıcı fiziksel bir cezaya çarptırılmaları yukarıda verilen âyetlerin zahirine ve ruhuna en uygun düșen bir anlamdır. Bu konuya dair Taberî̀nin, meshin manevî olarak gerçekleştiğini ifade eden Mücâhid'in görüşüne verdiği cevap şu şekildedir: "Onlar, hakikaten maymuna ve domuza çevrilmediler' demek, 'Avlanma yasağını delen Yahudi grubunun başına herhangi bir ceza-i müeyyide uygulanmadı' demekle aynı anlama gelmektedir." 104

4. Meshe maruz kalanların manevî yönden bir ahlakî çöküntüye uğradıklarını, şeklen bir değişikliğin gerçekleşmiş olması halinde söz konusu İsrailoğullarının nesillerinin devam etmemesi gerektiği ${ }^{105}$ gerekçesini ileri sürenlerin iddiaları pek ikna edici değildir. Zira sözü edilen vakada İsrailoğulları topluluğunun tamamı meshe uğratılmamıştır. Bu topluluktan sadece "Eyle" denilen deniz kıyısındaki bir şehirde ikamet eden ve yasağa uymayanlar maymun kılığına sokuldukları ifade edilmiştir. Dahası bu kent halkı içerisinde olup da yasağı çiğneyenleri uyaranları Allah istisna ederek onlara aynı cezayı uygulamadığını bildirmektedir. ${ }^{106}$ Hatta yukarıda da ifade edildiği gibi bu şehir halkından yasağı açıkça çiğneyen kişileri Allah'ın zaten helak edeceğini ve onları uyarmanın bir fayda sağlamayacağını söyleyen üçüncü grubun da kurtulmuş olabileceğini hesaba katarsak tüm İsrailoğulları topluluğunun tamamının değil, sadece burada yaşayanların üçte birinin maymuna çevrildiğini kabul etmek durumundayız. Dolayısıyla bu cezayla birlikte İsrailoğulları soyunun tarihin bu devresinde inkıtaa uğradığını ifade etmek mümkün değildir.

102 İsfahânî, "tms", 524.

103 Yazır, Hak Dini Kur'ân Dili, 2/569; Ateş, Yüce Kur'ân'ın Çağdaş Tefsiri, 2/298-299.

104 Taberî, Câmi'u'l-beyân, 1/263.

105 Reșid Riza, Tefsîrül-menâr, 1/286.

106 el-A'râf 7/165. 
Kısaca ifade etmek gerekirse hem ayetlerde geçen "fısk", "nekâl", "tams" kavramlarının delaleti, hem Bakara suresinin 66. ayetinde olayın ibret-i alem olarak takdim edilmesi, hem de ayetlerin bağlamı birlikte değerlendirildiğinde mesh vakasının zahiri olarak gerçekleştiğine işaret etmektedir.

\section{Mesh Bir Reenkarnasyon mudur?}

Reenkarnasyon kavramı daha çok tecessüd-ü cedîd, ruhun herhangi bir cisimden başka bir cisme, bazen insandan hayvana, hayvandan insana geçmesi ve ruh göçü anlamlarında kullanılmaktadır. ${ }^{107}$ Kısaca bu kavram tekrar bedene bürünmeyi ifade etmektedir. Çok yakın anlamda kullanılan tenasüh de ölen insandan ayrılan ruhun başka bir bedenle yeniden dünyaya gelmesidir. ${ }^{108}$ Yeni bir bedenle ortaya çıkma şeklinde ortak kullanıma karşın aralarında mahiyet farkının da bulunduğu şu şekilde ifade edilebilir: Tenasühte ceza ve mükâfata göre tekrar bedenlenme bulunmadığı için bir tekâmül fikrinden söz edilemezken; ${ }^{109}$ reenkarnasyonda ise dünya özlemi duyan ruhların tekâmül maksadıyla dünyaya tekrar gelişinden bahsedilebilir. ${ }^{110}$ İște bu bağlamda mesh vakası da acaba tenasüh veya reenkarnasyonun bir parçası, bir türü sayılabilir mi? Bu konunun da irdelenip açıklığa kavuşturulması yararlı olacaktır.

Yüce Allah'ın çeşitli vesilelerle tehdit etmesine rağmen yasaklarına uymayanları tarihin belli bir döneminde çok şiddetli bir azap türü ile cezalandırarak maymuna ve domuza çevirme vakasını tefsir ilminin temel kurallarından biri olan "Sebebin hususiyeti, nassın umumiyetine engel değildir" kaidesi gereğince sürekli meydana gelebilecek bir durum olduğu ve bu vakanın bir tür reenkarnasyon sayılabileceği111 fikri de gündeme getirilmekte ve tartışılmaktadır.

Kur'ân'da anlatılan mesh hadisesinin ne alenen ne de zımnen kıyamete kadar devam edeceğini gösteren herhangi bir âyet yoktur. Allah'ın sınırlarını kendisinin belirlediği yasakları çiğneyen kişi veya kavimleri dilediğinde maymuna, domuza ve hatta başka bir hayvana çevirmesi mümkündür.

107 Ali İhsan Yitik, "Tenasüh”, Türkiye Diyanet Vakfi İslâm Ansiklopedisi (İstanbul: TDV Yayınları, 2011), 40/443. Daha geniş bilgi için bk. Veysel Güllüce, Kur'ân Işığında Reenkarnasyon (İstanbul: Rağbet Yayınları, 2014), 37.

${ }^{108}$ Ali b. Muhammed Seyyid Şerif Cürcânî, Şerhü'l-mevâkıf (İstanbul: Dâru Tıba'âti'l-Âmire, h. 1311), 8/300.

109 Bedri Ruhselman, Ruh ve Kâinat (İstanbul: RM. Yayınları, 1997), 152.

110 Güllüce, Kur'ân Ișığında Reenkarnasyon, 38.

111 Yaşar Nuri Öztürk, Kur'ân'ın Temel Kavramları (İstanbul: Yeni Boyut Yayınları, 1993), 363-365. 
Bunun aksini düşünmek temelsiz ve geçersiz bir iddia olarak kabul edilmesi gerekir. Ayrıca insanın sürekli olarak hayvanlara dönüştürüldügüne dair biyoloji, genetik gibi pozitif bilimlerin verileriyle de en azından dönüşümün daimi olarak gerçekleştiğinin açıklanma zorunluluğu vardır. Oysa bugüne kadar bu durumu doğrulayacak herhangi bir somut bir bulguya da rastlanılmamıștır. Dolayısıyla mesh olayının devam edeceğini savunmak mümkün değildir.

Meshin bir tür reenkarnasyon olabileceği görüşüne gelince; bu görüş Kur'ân'ın takdim ettiği genel ilkeler çerçevesinde değerlendirildiğinde Kur'ân'ın, reenkarnasyonun olabileceğine değil, olamayacağına dair daha güçlü delillerin olduğu görülecektir. Örneğin "Nihayet onlardan birine ölüm geldiği zaman: "Rabbim, der, beni geri döndürünüz! Terk ettiğim dünyada yararlı bir iş yapayım." Hayır, bu onun söylediği bir sözdür. Önlerinde tâ diriltilecekleri güne kadar bir berzah vardır." (el-Mü'minûn 23/99-100) mealindeki âyet reenkarnasyonun olamayacağını gösteren delillerden birisidir.

Kur'ân'da anlatılan mesh hadisesinin bir tür reenkarnasyon olabileceği görüşü dayanaktan yoksun bir iddiadır. Zira reenkarnasyon bir tekâmül (gelişme, olgunlaşma) sürecinin ifadesidir. Bu anlayışına göre dünya hayatında kendilerine verilen süreyi amacına yönelik kullanamayanlar, yeni bir beden verilmesi suretiyle dünya hayatına yeniden gönderilip tekrar yaşama imkânına kavuşturulmakta ve böylece tekâmüllerini tamamlamaları için kendilerine yeni bir fırsat verilmiş olmaktadır. Oysa mesh hadisesinde yaşananlara bakıldığında günahkârlara yeni bir firsat verme yerine onlara bir ceza verildiği görülecektir. Meshe tabi tutulan insanlar, Yüce Allah'ın indirdiği hükümleri tanımamakta ısrar ettikleri için Allah'ın gazabına muhatap olarak bazı hayvanlara dönüştürülmüşlerdir. Dolayısıyla burada bir reenkarnasyonun varlığından söz edilemez. ${ }^{112}$

Reenkarnasyonda kişinin iradesini kullanarak istikametini bulması için kendisine yeni bir şans verilmesi söz konusu iken, burada hayvana dönüştürülen insanların iradeleri, dolayısıyla istikamette yürüme şansları ellerinden alınmıștır.

Bazı âlimler meshe uğrayanların maymun halinde yaşamaya devam ettiklerini ve günümüzdeki maymunların onların nesillerinden geldiklerini iddia etmektedirler. Oysa Hz. Muhammed'in "Allah bir nesli helak etti mi

112 Ebûbekir Sifil, Modern İslâm Düşüncesi Tenkidi -I (İstanbul: Kayıhan Yayınları, 1997), 193. 
ondan nesil bırakmaz."113 hadisinden cezaya çarptırılıp maymuna çevrilen insanların soyunun devam etmeyeceği açıkça anlaşılmaktadır. Ayrıca burada şu hususa dikkat çekmek gerekir ki, bu vaka ile beraber maymunlar ve domuzlar hayat sahnesinde yerini almış değillerdir. Daha önceden beri yaşıyor olduklarını Hz. Peygamber de ifade etmektedir. ${ }^{114}$ Yine bu vaka sonrasında eğer maymun ve domuzlar hayata yeni başlamış olsalardı bu durum mutlaka tarih kitaplarında yerini alacaktı. Oysa böyle bir vaka sonucu bu hayvanların hayata ilk olarak başladığını belirten hiçbir ciddi tarih kaynağı mevcut değildir. Dolayısıyla âyetlerde belirtilen mesh hadisesinin istisnaî bir durum arz ettiği, bir neslin başka bir nesle dönüşümüyle bir bağlantısının bulunmadığı rahatlıkla söylenebilir.

Şu halde günümüzde yaşayan maymunların insanlardan dönüşümle maymun olduğu fikrinin geçersizliği kadar, insanların tarihi süreç içerisinde evrim neticesinde maymunlarla aynı atadan türemiş olduğu düşüncesi de o derece tutarsız ve dayanaktan yoksun bir iddia olsa gerektir. Zira zaman içerisinde canlıların çeşitli aşamalardan geçerek olgunlaşıp geliştiği görüşü doğru olsa da düşünebilme, yorumlayabilme gibi sadece insana has olan yeteneklerin türler arası geçişinin mümkün olmadığı açıktır. Yüce Allah ilk yaratılışta insan ve hayvan türlerini farklı özelliklerle donatarak vücuda getirmiştir. İnsanın maymundan türediği iddiasının geçersizliği şu soruyla da ortaya konabilir: Günümüzde yaşayan maymunlar neden insana dönüşmediler? Yeryüzünde halife ${ }^{115}$ olarak yaratılan insanın dünyaya teşrifiyle beraber doğruyu-yanlışı, iyiyi- kötüyü kavrayabilecek ölçüde şuur ve irade sahibi kılınmıştır. Dolayısıyla sadece içgüdü özelliğine sahip maymundan hem içgüdü hem de şuur sahibi insana dönüşümü mümkün değildir. Şayet insan maymundan veya herhangi bir hayvandan türemiş olsaydı Kur'ân'da ifade edilen "Ey insanlar, sizi bir tek nefisten yaratan ve ondan eşini yaratıp ikisinden birçok erkekler ve kadınlar üreten Rabbinizden korkun." (en-Nisâ 4/1) âyetinin yerine başka bir ifade kullanılırdı.

İnsanın maymundan türediği şeklindeki iddia bağlamında şu hususu da ayrıca belirtmek gerekir. İbn Abbas'tan aktarılan bir rivayette meshedilerek maymuna çevrilen insanların, üç gün bu aşağıllk durumda yaşadıktan sonra geri dönüşü olmayan bir sürece girmiş oldukları, hiçbir

113 Müslim, "Kader”, 32-33. Bu konuya dair daha geniș izahlar için bk. Âlûsî, Rûhü'l-me'ânî, 1/283-285.

114 "Maymun ve domuzlar daha önce de vardı." (Bk. Ebû Abdullah Ahmed b. Muhammed eș-Şeybânî İbn Hanbel, el-Müsned (İstanbul: Çağrı Yayınları, 1412/1992), 1/390, 413. 115 el-Bakara 2/30. 
nesil bırakmadıkları, hatta bu zaman zarfında hiç yiyip içmedikleri116 şeklindeki ifade, maymun soyunun insandan oluştuğuna dair iddiayı geçersiz kılacak yetkin bir cevap hüviyetindedir. Dolayısıyla gerek evrim teorisi ve gerekse günümüzde yaşayan maymunların insandan oluştuğu iddiaları açık bir şekilde geçersiz olmaktadır.

Meshin bir tür reenkarnasyon olamayacağı şu açıdan da mümkün değildir. Mesh vakasında ruhun bir başka bedene intikali söz konusu değil, sadece ruhun içinde bulunduğu beden değiştirilmektedir. Yine bu bağlamda meshte bir ölümden bahsedilemezken, reenkarnasyonda ise ruhun, ölümden sonra başka bir varlığa geçişten söz edilmektedir. ${ }^{117}$

Netice itibariyle Allah, insanı mahlûkatın en değerlisi olarak insan biçiminde, maymunu veya diğer hayvanları da kendi sistemleri içinde farklı bir tür olarak ve yine farklı siret ve surette yaratmıștır. Bir insanı hayvandan veya bir hayvanı insandan suretini çevirip farklı bir varlık olarak vücuda getirebilen bir yaratıcı bu varlıkları kendi dünyaları içinde bir değer olarak ayrı ayrı yaratmaya kadirdir.

\section{Sonuç}

Kur'ân'ın inceliklerini araştıran ilimlerden biri olan hakikat ve mecaz ilmi, Kur'ân ilimleri arasında en fazla üzerinde tartışılan konular arasında yer alır. İslâm bilginlerinin bir kısmı Kur'ân'da mecazın olmadığını iddia ederken, çoğunluğu da mecazın varlığını kabul etmekte ve onun Kur'ân'ın edebi üslubuna zenginlik kattığını, hakikatten daha beliğ bir anlatım şekli olduğunu belirtmektedirler.

Yüce Allah, tarihin farklı dönemlerinde inananların uyması için değişik kurallar koymuştur. Bu kurallardan bazıları emir niteliğinde, bazıları ise yasak kapsamındadır. Daha çok yasak kapsamında olan kuralların çiğnenmesi durumunda sahiplerini yere batırma, suda boğma, üzerlerine taş yağdırma gibi farklı usullerle cezalandırmıștır. Bu usullerden biri de maymuna ve domuza çevirme (mesh) şeklinde gerçekleştirilmiştir.

Kur'ân'ın pek çok âyetinde söz konusu olan anlatım tarzının kimi yerde geçmiş milletlerin hayatlarının anlatıldığı kıssalarda varlığını görmek mümkündür. Bu kıssalardan biri haftanın cumartesi gününde avlanma yasağı konan İsrailoğullarından bir grubun cezalandırılması konusudur. Sözü edilen kıssada yasağa uymayan grubun maymuna ve domuza dönüştürülmesi meselesi müfessirler arasında yoğun tartışmalara yol

116 Taberî, Câmi'u'l-beyân, 1/261; İbn Kesir, Tefsîrü'l-Kur'âni'l-'Azîm, 1/105, 2/258.

117 Güllüce, Kur'ân Ișığında Reenkarnasyon, 17. 
açmıştır.

Mesh hadisesinin anlatıldı̆̆ âyetlerde olayın büyüklüğüne ve ibret kaynağı oluşuna dikkat çekilmesi, ilgili âyetlerde yer alan kelimelerin vurgulu kelimelerden seçilmiş olması, "maymun olunuz" gibi benzetme değil de, doğrudan kevnî/fiilî sunum ifadelerinin mevcudiyeti birlikte değerlendirildiğinde olayın karakter değişimi yerine fiziksel dönüşümün gerçekleştiği söylenebilir. Ayrıca âyetlerin siyak-sibak ilişkisi, Yahudilerin bu olaydan haberdar olduklarının bildirilmiş olması da bu hadisenin şeklen gerçekleşmiş olduğu görüşünü güçlendirmektedir.

Şüphesiz Allah'ın koyduğu yasağa uygun hareket etmeyen İsrailoğullarından bir gruba uygulanan cezanın fiziksel olarak gerçekleşmiş olduğu düşüncesinden hareketle maksadın sonraki nesilleri caydırma olduğunu belirtmek gerekir. Bu kapsamda İsrailoğullarının maymuna çevrilmesi ile sonuçlanan bu vaka ile diğer cezalandırılan toplulukların helak edilme sonuçları açısından birbirine benzerlik göstermesi ve bunların bize aktarılmasında ibret vurgusunun öne çıktığı aşikârdır.

Mesh hadisesinin yaşandığı şehir halkının bir kısmının maymuna dönüştürülmüş olmasının bir tür reenkarnasyon olduğuna ilişkin kimi yorumların, reenkarnasyonun iddia edilen oluşum biçimiyle tam örtüşmemesi nedeniyle herhangi bir reenkarnasyon fikrinden söz edilemez. Zira bu olay sadece bir kereye mahsus gerçekleştirilmiş olup reenkarnasyonun sürekli geliş-gidişi ifade eden tekâmül anlayışıyla çelişmektedir. Meshe uğratılanlarının tamamının bir ceza karşılığında üç günden fazla yaşamamış olmaları da bu dönüşüm hadisesinin reenkarnasyon olamayacağını göstermektedir.

\section{KAYNAKÇA}

AĞKUŞ, Yusuf - ALTUNCU, Abdullah. "Yahudi Kutsal Metinlerinde Ve Kur'ân'da Şabat (Cumartesi) Yasakları Ve Mesh Hadisesi". Insan Ve Toplum Bilimleri Araştırmaları Dergisi 6/5 (2017), 2775-2794.

AKDEMIR, Hikmet. "Kur'ân-I Kerim'de Mecazın Varlığı Problemi”. Harran Üniversitesi İlahiyat Fakültesi Dergisi 4/4 (1998), 59-90.

ÂLÛSî, Muhammed Ebü'l-Fazl. Rûhü'l-Me'ânî Fî Tefsîri'l-Kur'âni'l-'Azîm Ve'sSeb'i'l-Mesânî. 30 Cilt. Beyrut: Dâru İhyâi't-Türâsi'l-Arabî, Ts.

ÂMÎDÎ, Ali B. Muhammed. El-İhkâm Fî Usûli'l-Ahkâm. 4 Cilt. Beyrut: ElMektebetü'l-İslâm, 1402. 
ATEŞ, Süleyman. Yüce Kur'ân'ı́n Çağdaş Tefsiri. 11 Cilt. İstanbul: Yeni Ufuklar Neşriyat, 1989.

BEGAVÎ, Ebû Muhammed Hüseyin B. Mesud. Me'âlimü't-Tenzîl. 8 Cilt. Y. Y.: Dâru Tayyibe Li'n-Neşr, 1997.

BEYZÂVÎ, Abdullah B. Ömer B. Muhammed. Envârü't-Tenzîl Ve Esrârü't-Te'vîl. 2 Cilt. Misır: Matba'Atu Mustafa Muhammed, Ts.

BİLGE, Mustafa L. "Akabe". Türkiye Diyanet Vakfi İslâm Ansiklopedisi. 2/209210. İstanbul: Tdv Yayınları, 1989.

BİRIŞIK, Abdülhamit. "Mecâzu'l-Kur'ân”. Türkiye Diyanet Vakfı İslâm Ansiklopedisi. 28/323. Ankara: Tdv Yayınları, 2003.

BUHÂRÎ, Ebû Abdullâh Muhammed B. İsmâîl B. İbrâhîm El-. El-Câmi'u'sSahîh. İstanbul: Çağrı Yayınları, 1981.

CEVDET PAŞA, Ahmet. Mecelle-İ Ahkâm-I Adliyye. Dersaadet: Matbaa-İ Osmaniyye, 1308.

CEVHERÎ, İsmail B. Hammâd. Es-Sihâh: Tâcü'l-Luğe Ve Sihâhi'l-Arabiyye. 6 Cilt. Beyrut: Dârü'l-İlm, 4., 19871407.

CÜRCÂNÎ, Ali B. Muhammed Seyyid Şerif. Şerhü'l-Mevâkıf. İstanbul: Dâru Tiba'âti'l-Âmire, 1311.

CÜRCÂNÎ, Ali B. Muhammed Seyyid Şerif. Kitâbu't-Tâ'rifât. Lübnan: Lübnan: Mektebetü Lübnan, 1985.

ÇAĞIL, Necdet. “Hakikat-Mecaz Kutuplaşması Bağlamında Kur'an'da Temsilî (Simgesel) Anlatım”. İslâmî İlimler Dergisi 8/1 (2013), 95-114.

ÇETIN, Abdurrahman. Kur'ân İlimleri Ve Kur'ân-I Kerim Tarihi. İstanbul: Dergâh Yayınları, 3. Basım., 2014.

DEMIRCI, Muhsin. Tefsirde Metodolojik Sorunlar. İstanbul: İfav Yayınları, 2. Basım., 2017.

EBÛ HAYYAN, Muhammed B. Yûsuf B. Ali B. Yûsuf B. Hayyan El-Endelusî. ElBahrü'l-Muhît. 8 Cilt. Riyad: Mektebetü Ve Metâbi'u'n-Nasri'l-Cideyșe, Ts.

ERTEN, Mevlüt. "Kur'ân'da Hakikat Ve Mecazın Tespitinde Bağlamın Önemi”. İslâmî Illimler Dergisi 8/1 (2013), 161-182.

ESED, Muhammed. Kur'ân Mesajı Meal Ve Tefsîr. Çev. Ahmet Ertürk, Cahit Koytak. İstanbul: İşaret Yayınları, 2002.

FÎRÛZÂBÂDÎ, Mecduddin Muhammed B. Yakub. Besâîru Zevi't-Temyîz Fî Letâifi'l-Kitâbi'l-Azîz. 6 Cilt. Kahire: İhyâu't-Türasi'l-İslamî, 3. Basım, 1416. 
GÜLLÜCE, Veysel. Kur'ân Işığında Reenkarnasyon. İstanbul: Rağbet Yayınları, 2014.

GÜNALTAY, M. Şemseddin. Felsefe-İ Ûlâ İsbat-I Vacib Ve Ruh Nazariyeleri. Haz. Nuri Çolak. İstanbul: İnsan Yayınları, 1994.

GÜRKAN, Salime Leyla. "Sebt". Türkiye Diyanet Vakfı İslâm Ansiklopedisi. 36/256-258. İstanbul: Tdv Yayınları, 2009.

HAMEVÎ, Yakut. Mu'cemü'l-Buldân. 5 Cilt. Beyrut: Dârü'l-Fikr, 1995.

İbn ÂŞÛR, Muhammed Et-Tahir. Et-Tahrîr Ve't-Tenvîr. 30 Cilt. Tûnus: Dârü'tTunusiyye, 1984.

İbn HANBEL, Ebû Abdullah Ahmed B. Muhammed Eş-Şeybânî. El-Müsned. İstanbul: Çağrı Yayınları, 2. Basım., 1412.

İbn KESİR, Ebü'l-Fidâ İmâdüddîn İsmâil. Tefsîrü'l-Kur'âni'l-'azîm. 4 Cilt. Beyrût: Dâru İhyâi't-Türâsi'l-Arabî, 1388.

İbn MANZÛR, Ebü'l-Fazl Cemâlüddîn Muhammed B. Mukerrem B. Alî. Lisânü'l-Arab. 15 Cilt. Beyrût: Dâru Lisâni'l-Arab, Ts.

ÎCî, Azduddin Abdurrahman B. Ahmed. Kitâbü'l-Mevâklf. Beyrut: Dârü'l-Cîl, 1997.

İSFAHÂNÎ, Rağıb. Müfredâtu Elfâzi'l-Kur'ân. Thk. Safvân Adnan Dâvûdî. Dımeşk: Dârü'l-Kalem, 3. Basım, 20021423.

KARATAŞ, Ali. “Müteşabih Ayetler Ve Te'vili”. Günümüz Tefsir Problemleri. Ed. Ali Karataş - Yunus Emre Gördük. 135-155. Ankara: Bilay Yayınları, 2018.

KARSLI, H. İbrahim. Kur'ân'ı Anlamaya Giriş. Ankara: Dib Yayınları, 3. Basım, 2019.

KASAPOĞLU, Abdurrahman. "Kur'ân'da Hayvan Davranışlarına Benzetilen İnsan Karakterleri". Fırat Üniversitesi İlahiyat Fakültesi Dergis 11/1 (2006), 47-75.

KASİMÎ, Cemâleddin. Tefsir İlminin Temel Meseleleri. Çev. Sezai Özel. İstanbul: İz Yayıncllık, 1990.

KAZVINî, Zekeriyya B. Muhammed. Âsârü'l-Bilâd Ve Ahbârü'l-'ibâd. Beyrut: Dâru Sadr, Ts.

KESLER, Muhammed Fatih. "Kur'ân-I Kerim'de Tarihsel Bir Gönderme (İnsanın Maymunlaşması Ya Da Kimlik Kaybı". Diyanet İlmî Dergi 51/4 (2015), 103-122.

KILIÇ, Sadık. Kur'ân'da Günah Kavramı. Konya: Hibaş Yayınları, 1984. 
KURBAN, Nur Ahmet. "İslâm Kaynaklarına Göre Sebt Yahudilerinin Maymuna Dönüştürülmesi Meselesi”. Marife Dergisi 13/1 (2013), 927.

KURTÛBî, Ebû Abdullah Muhammed B. Ahmed El-Ensârî. El-Câmi' Li Ahkâmi'l-Kur'ân. 20 Cilt. Beyrut: Dârü'l-Kâtibi'l-Arabî, 3. Basım, 1387.

MAKRIZÎ̃, Ali. El-Mevấîz Ve'l-I'tibâr Bi Zikri'l-Hitât Ve'l-Âsâr. Bulak: Y. Y., 1270.

MÂTÜRÎDÎ, Ebû Mansûr Muhammed B. Muhammed. Te'vilâtü'l-Kur'ân. 17 Cilt. İstanbul: Dâru'l-Mîzân, 2005.

MEVDÛDÎ, Ebü'l-A'lâ. Tefhîmü'l-Kur'ân. Çev. Muhammed Han Kayani - Vd. 7 Cilt. İstanbul: İnsan Yayınları, 1996.

MUKÂTiL B. SÜLEYMAN. Tefsîru Mukâtil B. Süleyman. 5 Cilt. Beyrut: Müessesetü't-Târîhi'l-Arabî, 1423.

MUTÇALI, Serdar. Arapça Türkçe Sözlük. İstanbul: Dağarcık Yayınları, 1995.

MÜCAHID, Ebü'l-Haccâc Mücahid B. Cebr. Tefsiru Mücahid. Thk. Abdurrahman Et-Tahir B. Muhammed. Beyrut: El-Menşûrâtü'lİlmiyye, Ts.

MÜSLİM, Ebü'l-Hüseyn Müslim B. El-Haccâc. El-Câmi'u's-Sahîh. İstanbul: Çağrı Yayınları, 1981.

OKUMUŞ, Mesut. “Ulûmü'l-Kur'ân”. Tefsir. Ed. M. Akif Koç. 316-423. Ankara: Grafiker Yayınları, 4. Basım, 2015.

ÖMER, Ahmed Muhtar. El-Mu'cemu'l-Mevsu'a Lielfâzi'í-Kur'âni'l-Kerîm Ve Kıra'atuhu. Riyad: Müessesetü Sütûri'l-Ma'rife, 1423.

ÖZTÜRK, Mustafa. Kur'ân'ın Mutezilî Yorumu Ebû Müslim El-İsfahânî Örneği. Ankara: Ankara Okulu Yayınları, 2. Basım, 2008.

ÖZTÜRK, Yaşar Nuri. Kur'ân'ın Temel Kavramları. İstanbul: Yeni Boyut Yayınları, 2. Basım, 1993.

RÂZÎ, Ebû Abdullah Fahrüddîn Muhammed B. Ömer B. Hüseyin. Et-Tefsîrü'lKebîr. 25 Cilt. Beyrût: Dâru İhyâi't-Türâsi'l-Arabî, 3. Basım, Ts.

REŞiD RIZA, Muhammed. Tefsîrü'l-Kur'âni'l-'azîm (Tefsîrü'l-Menâr). 12 Cilt. Beyrût: Dârü'l-Kütübi'l-İlmiyye, 1420.

RUHSELMAN, Bedri. Ruh Ve Kâinat. İstanbul: Rm. Yayınları, 1997.

SíFiL, Ebûbekir. Modern İslâm Düşüncesi Tenkidi -I. İstanbul: Kayıhan Yayınları, 1997.

SUBHİ Es-SÂLiH. Mebâhis Fî 'ulûmi'l-Kur'ân. İstanbul: : Dersaadet, Ts. 
SUYÛTÎ, Celâleddin Abdurrahman B. Ebî Bekr. El-İtkân Fî 'ulûmi'l-Kur'ân. 2 Cilt. Mısır: Mektebetü Dâri't-Türâs, Ts.

Kur'ân-I Kerim Ve Yüce Meali. Çev. Süleyman Ateș. İstanbul: Yeni Ufuklar Neşriyat, Ts.

ŞİMŞEK, Sait. Hayat Kaynağı Kur'ân Tefsiri. 5 Cilt. İstanbul: Beyan Yayınları, 2016.

TABERÎ, Ebû Ca'fer Muhammed B. Cerîr B. Yezîd. Câmi'u'l-Beyân Fî Tefsîri'lKur'ân. Beyrût: Dârü'l-Ma'Rife, 1407.

TURGAY, Nurettin. "Kur'ân'da Sebt Kavramı". Yalova Sosyal Bilimler Dergisi 2/4 (2012), 153-166.

YAZIR, Elmalılı M. Hamdi. Hak Dini Kur'ân Dili. Sad. İsmail Karaçam Vd. 10 Cilt. İstanbul: Azim Dağıtım, Ts.

YITİK, Ali İhsan. "Tenasüh". Türkiye Diyanet Vakfi İslâm Ansiklopedisi. 40/443-446. İstanbul: Tdv Yayınları, 2011.

YÜCEDAĞ, Tevfik. "Kur'ân Ve Mesh". Uludağ Üniversitesi İlahiyat Fakültesi Dergisi 20/2 (Ts.), 53-76.

ZEMAHŞERÎ, Ebü'l-Kâsım Mahmûd B. Ömer B. Muhammed El-Hârizmî. ElKeşşâf 'an Hakâiki't-Tenzîl Ve 'Uyûni'l-Ekâvîl. 4 Cilt. Beyrût: Dârü'l-Fikr, Ts.

ZERKEŞî, Bedruddîn Muhammed B. Abdullah. El-Burhân Fî 'ulûmi'l-Kur'ân. Thk. Muhammed Ebü'l-Fazl İbrahim. 4 Cilt. Beyrut: Dârü'l-Ma'rife, 2. Basım, Ts.

ZUHAYLÎ, Vehbe. Et-Tefsîrü'l-Münîr. 32 Cilt. Beyrut: Dârü'l-Fikri'l-Mu'âsır, 1411.

Kitabı Mukaddes. İstanbul: Yeni Yaşam Yayınları, 2016.

淡海 


\title{
THE EVENT OF SIMIANIZATION IN THE CONTEXT OF TRUTH AND METAPHOR IN THE QUR'AN
}

\author{
Mustafa TUNÇER ${ }^{\mathrm{a}}$
}

\section{Extended Abstract}

The science of truth and metaphor, which is one of the sciences that investigate the subtleties of the Qur'an, is among the most discussed topics among the sciences of the Qur'an. While some of the Islamic scholars claim that there is no metaphor in the Qur'an, most of them accept the existence of metaphors and state that the metaphors enrich the literary style of the Qur'an, being a more eloquent way of expression than the truth itself.

Although it is essential to use the literal meaning in the language, sometimes the figurative meaning can be used due to falling short of words or the inability to use words effectively. For example, if a person dies after saying that "I allocate my property to my children", all of his sons and daughters are understood as the literal meaning. As an example of figurative expression, if someone says that "I ate from that tree", he means eating fruits from that tree. According to those who do not agree on the usage of metaphors, someone only uses metaphors when he could not make himself understood. So, since it is unthinkable for Allah, there cannot be any metaphor in the Qur'an. According to the scholars who accept the existence of metaphors in the Qur'an, metaphor, as used in the Qur'an is not a metaphor in this sense. While Allah never had any difficulties in using metaphors, Allah used metaphors to increase the effectiveness of the meanings contained in the divine word and to add beauty and richness to the word.

Almighty Allah has set different rules for believers to obey in different periods of history. In the event that the rules covered by the prohibition were violated, Allah punished those who violated the prohibition by different

a Asst. Prof., Giresun University, mustafatuncer061@hotmail.com 
methods such as burying alive, drowning, raining stones on them. One of these procedures included transformation to an ape or a pig (simianization). The Qur'an narrates that the members of a Jewish group were transformed into apes because they ignored the warnings, just like the divine punishments faced by many communities that did not obey the rules in history. The results of this incident are evaluated by interpreters and comments are made around two different views on whether the concepts in the verses should be taken as literal or figurative. The former way of interpretation focuses on the fact that the literal meaning of the verse should be preferred, taking into account the emphasis that the incident served as a lesson to the world. According to the second view adopted by a few interpreters, it is considered that the figurative meanings of these verses should be used instead of their literal meanings.

Almighty Allah allocated Saturdays (Sabbath) to worship for Jews and prohibited them from working on Saturdays. However, it is narrated in the sources of interpretation that a group of them who did not obey the prohibition prepared pools on the shore and connected these pools to the sea through canals, and built barricades in these canals that prevent the return of fish, and thus, hunted the fish on Sundays. A Qur'an surah, which narrates the incident, states as follows: "You are already aware of those of you who broke the Sabbath. We said to them, "Be disgraced apes!" So, we made their fate an example to present and future generations, and a lesson to the Godfearing (al-Baqarah 2/65-66). It is a question of debate among the interpreters whether this incident refers to deformation in the bodies of those who break the prohibition or moral corruption. While the overwhelming majority of the interpreters claim that the simianization occurred physically, some interpreters claim that simianization is not a physical but a spiritual/moral transformation.

The context fiction of the verses in the surahs that narrate the case of simianization also indicates that the simianization physically took place. As a matter of fact, the word "rebelliousness" used at the end of verses 163 and 165 of the surah Al-A'râf, which narrates the same incident, shows the magnitude of the crime committed. In fact, the concept of "rebelliousness" is rather used in the Qur'an for actions that drag people to hell. Again, the term "example" used in the same verses, which narrates the case of simianization, was also used in matters where important warnings were made to deter serious crimes and the relevant punishments. Moreover, if it was only an |368 $\quad$ insult instead of a physical punishment, neither an actual punishment would be inflicted nor it would be a deterrent. It should also be noted that the fact 
that Allah draws attention to the deterrent aspect of the incident by the sentence "So, we made their fate an example to present and future generations, and a lesson to the God-fearing" (al-Baqara 2/66) serves as clear evidence of physical transformation in the incident. A case that may be a deterrent for future generations must have concrete implications so that lessons can be learned from that incident.

It can be easily said that the incident physically occurred considering the fact that attention is drawn to the magnitude and exemplariness of the incident, which comes up in four different surahs in the Qur'an, and the words in the relevant verses were chosen from among the accentuated words, and there are direct material/actual expressions instead of analogy, such as "be disgraced apes". Furthermore, the contextual relationship among the verses and the fact that the verses report that Jews were informed about this incident strengthens the view that this incident physically took place.

Since certain interpretations suggesting that the transformation of some of the people of the city where the incident took place into apes is some kind of reincarnation are not exactly consistent with the alleged form of reincarnation, any idea of reincarnation should be avoided. In fact, this incident took place only once, and it contradicts the conception of evolution, which expresses the continuous arrival and departure of reincarnation. The fact that all of those who were simianized did not live more than three days in return for a punishment shows that this transformation cannot be reincarnation.

In brief, this study opens up for discussion whether the simianization incident, which is mentioned in several surahs in the Qur'an, refers to a physical transformation as a punishment inflicted on those who defied the ban, or a moral insult deemed proper for them in the context of the science of truth-metaphor, and the study evaluates whether or not the said incident is associated with reincarnation.

Keywords: Tafsir, Qur'an, Truth and Metaphor, Simianization, Reincarnation.

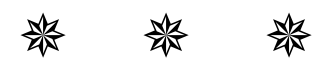

